HN9F/5U

\begin{tabular}{|c|c|c|c|c|}
\hline \multirow{3}{*}{$\begin{array}{l}\text { 2. ECN Category } \\
\text { (mark one) } \\
\text { Supplemental } \\
\text { Direct Revision } \\
\text { Change ECN } \\
\text { Temporary } \\
\text { Standby } \\
\text { Supersedure } \\
\text { Cancel/Void }\end{array}$} & \multirow{3}{*}{$\begin{array}{r}{[]} \\
{[X]} \\
{[]} \\
{[]} \\
{[]} \\
{[]} \\
{[]}\end{array}$} & $\begin{array}{l}\text { 3. Originator's Name. Organization. MSIN, } \\
\text { and Telephone No. } \\
\text { David Tedeschi.FDNW,E6-15,372-1485 }\end{array}$ & $\begin{array}{l}\text { 4. USQ Required? } \\
{[] \text { Yes }[X] \text { No }}\end{array}$ & $\begin{array}{l}\text { 5. Date } \\
\text { January 28, } 1999\end{array}$ \\
\hline & & $\begin{array}{l}\text { 6. Project Title/No./Work Order No. } \\
\text { Spent Nuclear Fuels/Fuel Retrieval }\end{array}$ & $\begin{array}{l}\text { 7. Bldg./Sys./Fac. No. } \\
100 \mathrm{~K} \text {. Konan Arm }\end{array}$ & $\begin{array}{l}\text { 8. Approval Designator } \\
N / A\end{array}$ \\
\hline & & $\begin{array}{l}\text { 9. Document Numbers Changed by this ECN } \\
\text { (includes sheet no. and rev.) } \\
\text { HNF-3526. Rev } 0\end{array}$ & 10. Related ECI & 11. Related PO No. \\
\hline
\end{tabular}

\begin{tabular}{|l|l|l|l|l|l|l}
\hline 12a. Modification Work & $\begin{array}{l}\text { 12b. Work Package } \\
\text { No. }\end{array}$ & 12c. Modification Work Complete & $\begin{array}{l}\text { 12d. Restored to Original Condi- } \\
\text { tion (Temp. or Standby ECN only) }\end{array}$
\end{tabular}

[] Yes (fill out Blk. 12b)

[X] No (NA Blks. 12b. 12c. 12d)

13a. Description of Change
N/A Design Authority/Cog, Engineer Signature \& Date
N/A Design Authority/Cog. Engineer Signature \& Date

This change adds testing information to the design package dealing with the large elastomer spring attached to the Fuel Retrieval Tool used on the FRS Konan Robot arm. See attached revision.

Details of additions:

1) Make a revision and incorporate the following changes to Design Package For Fuel Retrieval System Fuel Handling Tool Modification, HNF3526 rev 0.

a) Add to text section 5.3 a description of testing and it results.

b) Add "FRS Test Specification For the Evaluation of the Fuel Handling Tool's Large Elastomer Spring" to Appendix $C$

c) Add "FRS Test Report For the Evaluation of the Fuel Handling Tool's Large Elastomer Spring" To Appendix D.

d) Add Test Pictures to Appendix E.

14a. Justification (mark one)

Criteria Change $[X]$ Design Improvement [] Environmenta] As-Found $\quad[] \quad$ Facilitate Const

[] Const. Error/Omission

[] Facility Deactivation

14b. Justification Details

This change incorporates the verification of a design in the design package and helps keep all documents pertaining to this tool in a single package.

15. Distribution (include name. MSIN. and no. of copies) I COPY TO EACH DJ Tedeschi E6-15

BD Groth X3-88

Central Files B? -07 DOE/RL Reading Room H2-53

DR JACISSOM K5-22

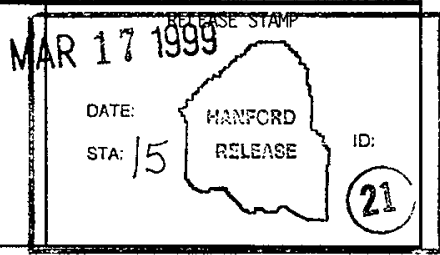


16. Design

Verification

Required

[] Yes

$[x]$ No

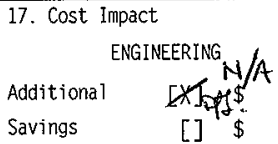

\begin{tabular}{l|ll} 
& Page 2 of 2 & 629888 \\
\hline
\end{tabular}

18. Schedule Impact (days)

Improvement

[N/A]

Delay

[]

$\begin{array}{lll}\text { Additional } & {[]} & \$ \\ \text { Savings } & {[]} & \$\end{array}$

19. Change Impact Review: Indicate the related documents (other than the engineering documents identified on Side 1) that will be affected by the change described in Block 13. Enter the affected document number in Block 20.

\begin{tabular}{|c|c|c|c|c|}
\hline $\mathrm{SOD} / 0 \mathrm{D}$ & [] & Seismic/Stress Analysis & [] & Tank Calibration Manual \\
\hline Functional design criteria & [] & Stress/Design Report & [] & Health Physics Procedure \\
\hline Operating Specification & [] & Interface Control Drawing & [] & Spares Multiple Unit Listing \\
\hline Criticality Specification & [] & Calibration Procedure & [] & Test Procedures/Specificatio \\
\hline Conceptual Design Report & [] & Installation Procedure & [] & Camponent Index \\
\hline Equipment Spec. & [] & Maintenance Procedure & {[]} & ASME Coded Item \\
\hline Const. Spec. & [] & Engineering Procedure & [] & Human Factor Consideration \\
\hline Procurement Spec. & [] & Operating instruction & [] & Computer Software \\
\hline Vendor Information & [] & Operating Procedure & [] & Electric Circuit Schedule \\
\hline OManual & {[]} & Operational Safety Requirement & [] & ICRS Procedure \\
\hline FSAR/SAR & [] & IEFO Drawing & [] & Process Control Manual/PJan \\
\hline Safety Equipnent List & [] & Cell Arrangement Drawing & [] & Process Flow Chart \\
\hline Radiation Work Permit & [] & Essential Material Specification & [] & Purchase Requisition \\
\hline Environmental Impact Statement & {[]} & Fac. Proc. Samp. Schedule & [] & Tickler File \\
\hline Environmental Report & {[]} & Inspection Plan & [] & \\
\hline Environmental Permit & [] & Inventory Adjustnent Request & [] & \\
\hline
\end{tabular}

20. Other Affected Documents: (NOTE: Documents listed below will not be revised by this ECN.) Signatures below indicate that the signing organization has been notified of other affected documents listed below.

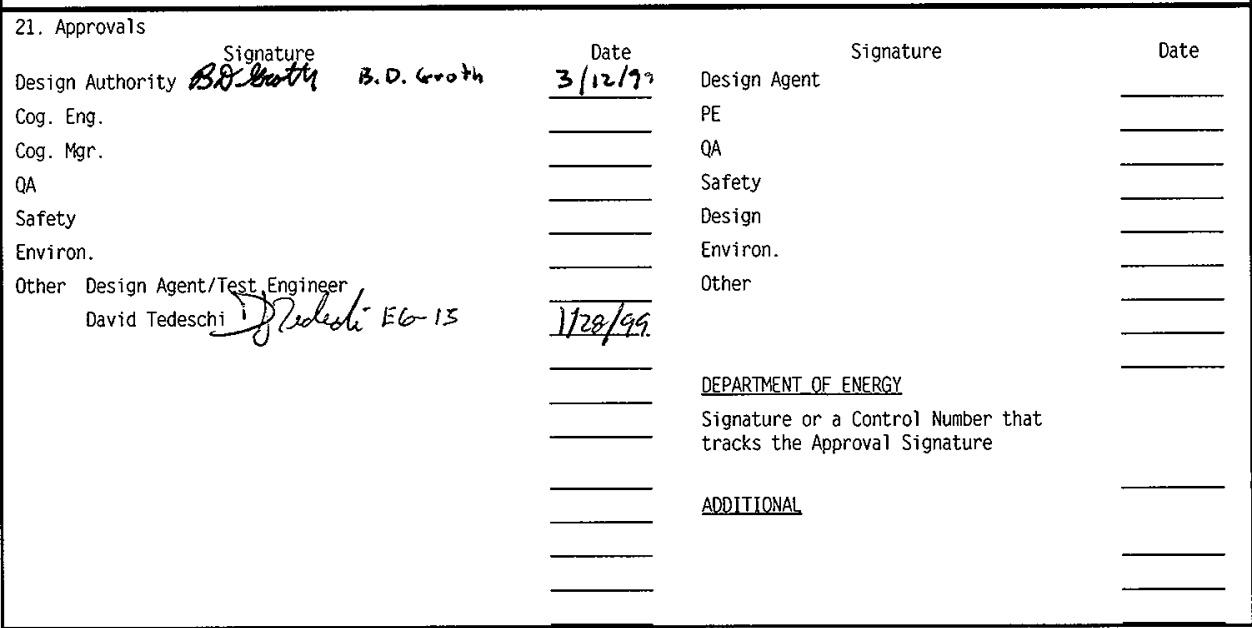




\section{Design Package For Fuel Retrieval System Fuel Handling Tool Modification}

\section{David Tedeschi}

for Duke Engineering and Services Hanford, Richland, WA 99352

U.S. Department of Energy Coniract DE-AC06-96RL13200

EDT/ECN: 609377

Org Code: 21371

B\&R Code: EW 7040000
UC: 2050

Charge Code: CACN: 105491 COA: DM00

Total Pages: $55_{k N}$

Key Words: Spent Nuclear Fuel, Stinger, Fuel Handling Tool, Fuel Retrieval System, Elastomer

Abstract: This is a design package that contains the details for a modification to a tool used for moving fuel elements during loading of MCO Fuel Baskets for the Fuel Retrieval System. The tool is called the fuel handling tool (or stinger). This document contains requirements, development design information, tests, and test reports.

TRADEMARK DISCLAIMER. Reference herein to any specific commercial product, process, or service by trade name, trademark, manufacturer, or otherwise, does not necessarily constitute or imply its endorsement, recommendation, or favoring by the United States Government or any agency thereof or its contractors or subcontractors.

Printed in the United States of America. To obtain copies of this document, contact: Document Control Services, P.O. Box 950, Mailstop H6-08, Richland WA 99352, Phone (509) 372-2420; Fax (509) 376-4989.
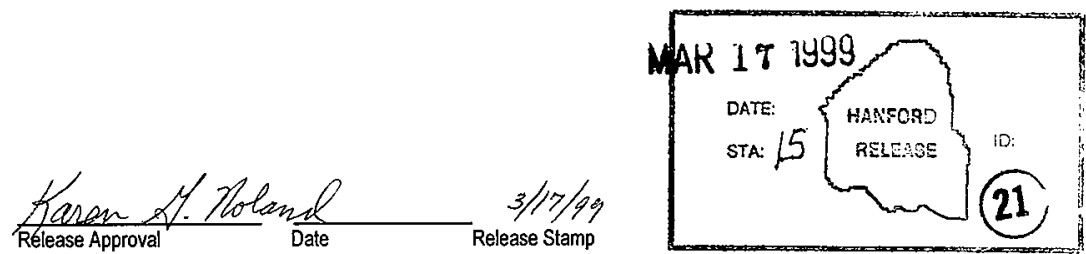

\section{Approved for Public Release}




\section{RECORD OF REVISION}

(2) Title

Design Package For Fuel Retrieval System Fuel Handling Tool Modification

\section{Change Control Record}

(3) Revision

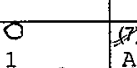

(4) Description of Change - Replace, Add, and Delete Pages (7) EDT-609377 $11 / 9 / 98$

RS per EcN- testigg documentation
Authorized for Release

\begin{tabular}{l|ll} 
(5) Cog. Engr. & (6) Cog. Mgr. Date
\end{tabular}

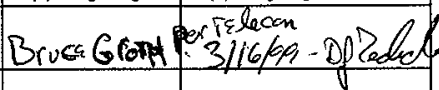

1




\section{Design Package \\ for}

Fuel Retrieval System Fuel Handling Tool Modification

HNF-3526 Rev 1

January 28, 1999

By David Tedeschi

of

Flour Daniel Northwest

1200 Jadwin

Richland, WA 99352

For Bruce Groth

of

Duke Engineering \& Services Company Hanford

P.O. Box 350

Richland, WA 99352 


\section{Design Package for Fuel Retrieval System Fuel Handling Tool Modification}

January 28, 1999

\subsection{Introduction}

The Fuel Retrieval System (FRS) Subproject at Hanford's $100 \mathrm{~K}$ basins Spent Nuclear Fuel Project has employed robotic arms (named Konans) to load fuel elements into long term storage baskets.

The robotic arms use a fuel handling tool (also known as the "stinger tool") to relocate an inner and or outer fuel element. The stinger moves an element by being inserted inside of the element and opening the robotic arm's jaw. Opening of the jaw causes an elastomer spring on the stinger to expand past the inside diameter of the element. The spring exerts enough force against the inner diameter of the element's wall that it can be lifted.

The robotic arms are being tested and being used for training. Testing and training has shown that the current stinger design is failing to meet its usage requirements. The elastomer springs are failing prematurely and adjustments are required after operating it for a short period. This design package will modify the current design of the stinger and bring it up to the expected requirements.

\subsection{Scope}

\subsection{Objectives}

The scope of this design package is to document the design, fabrication, and testing of stinger tool modification.

\subsection{Products Delivered}

This package will deliver the following:

Documents

1) This document, which includes product requirements, analysis, graphical depictions, tests and reports.

2) Hanford formatted drawings or information for upgrades to the vendor drawings.

3) Vendor information

4) Procurement documentation

\section{Hardware}

1) Modified stinger tool. 


\section{Design Package for Fuel Retrieval System Fuel Handling Tool Modification}

January 28, 1999

HNF-3526 Rev. 1

Page 3

\subsection{Brief Description of Problem}

The stinger functions by using a wire rope attached to Konan's robotic hand via a holding block mechanism. As the robotic jaw opens, the wire rope is pulled. Pulling on the wire rope results in the elastomer springs being compressed and expanding. The stinger is placed into either an inner or outer fuel element. When the elastomer spring expands, it applies a force against the inner wall of the fuel element. A fuel element can be lifted using the stinger tool, as long as the frictional forces between the wall of the rod and the elastomer spring are not overcome by the weight of the fuel element. A sketch of the stinger is shown in Appendix A.

\subsection{Products Requirements and Constraints}

The general design requirements/criteria for the Spent Nuclear Fuel Project Fuel Retrieval subproject is in HNF-S-0461, Specification For Design Of The SNF Project Fuel Retrieval Subproject. The following requirements are additional to this and apply to the stinger tool.

\subsection{Dimensional/Physical Constraints}

a) Large and small elastomer springs must be able to accommodate the following dimensions:

Fuel Elements

The largest diameters will be the worst case and will therefore be listed Outer fuel element inside diameter: $1.779 \mathrm{in}$. Inner fuel element inside diameter: $\underline{0.492}$ in (Taken from drawing number H-1-39775) Assume both inner and outer fuel element weighs approximately $55 \mathrm{lbs}$. where the outer is 38 and the inner is 17. Reference HNF-SD-SNF-TI-009, rev. 2, 105-K Basin Material Design Basis Feed Description for Spent Nuclear Fuel Project Facilities.

\subsection{Environmental Constraints}

a) Stinger material must be able to withstand the effects of high radiation field of $40 \mathrm{rem} / \mathrm{hr}$. This value is a conservative interpretation of BNFL Inc. Report L/B-SD-SNF-RPT-04, Radiological Shielding Design Plan for the SNF Fuel Retrieval Project.

b) Stinger must be able to be submersed in deionized water at a temperature of $50^{\circ} \mathrm{F}$ for a period of its design life. 


\section{Design Package for Fuel Retrieval System \\ Fuel Handling Tool Modification}

January 28, 1999

HNF-3526 Rev. 1

Page 4

\subsection{Operational Requirements}

a) Stinger should be able to operate for a period of 3 months assuming 3 shifts per day, 7 days a week, and process about 140 fuel assemblies per day. Cold validation testing (report not yet available) has shown that there will only be 140 outer fuel elements processed per day and inner elements will not require the use of a stinger tool for processing.

b) Stinger shall overcome weight of a fuel element and not slip when being lifted. Required force that stinger's elastomer spring must exert on the outer fuel elements inner diameter is $278 \mathrm{lbf}$ assuming a reliability factor of 2 . See Appendix $B$ for calculations.

b) Stinger shall be able to operate under 16-20 feet of water.

c) Springs must be able to be fully compressed in the elastic region at 700 lbs. ( \pm 100 lbs.)

d) Elastomer springs shall maintain diameter dimensions shown in the figure. Length to be determined.

e) Elastomer spring housings shall not touch when either the small or large springs are compressed. If the two pieces of the house do touch, this will place a high stress on the wire rope and thus produce a failure.

\subsection{Maintenance Requirements}

a) Stinger tools will be thrown away unless there is an inexpensive method for replacing failed parts.

\subsection{Applicable Laws, Regulations, and Standards}

Applicable Fluor Daniel Hanford engineering procedures shall be used for documenting development stages of design, reviews, and approvals of engineering documents.

\subsection{Development of Product}

\subsection{Management of Task}

\subsubsection{Engineering}

Engineering will be done using Fluor Daniel Northwest.

Documents will be reviewed and approved by Duke Engineering \& Services Hanford. 


\section{Design Package for Fuel Retrieval System \\ Fuel Handling Tool Modification}

January 28, 1999

\subsubsection{Procurement}

Developmental materials will be procured using credit cards from Numatec. Final parts will be ordered based on who is awarded the final fabrication.

\subsubsection{Fabrication / Construction}

Fluor Daniel Northwest will be responsible for fabrication and construction of prototype and the final design.

\subsubsection{Prototype}

Fluor Daniel Northwest will control prototype equipment. The Engineer in charge will redline control of prototype fabrication drawings/sketches. Prototype testing and test results will be documented. The prototype information will be incorporated into this document.

\subsection{Discussion of Development}

The stinger tool has undergone several operational tests, which revealed under dry conditions that the current design requires periodic tightening adjustments to continue its use. This is an unacceptable practice because adjustments will not be accessible and if they were, they could be highly radioactively contaminated.

It was then determined by Duke/PNNL to fix the large spring and concentrate on the small one once good results were achieved. It was also decided to maintain the current design but change the spring's material property.

Extensive research was done to find manufacturers that made urethane springs. Finally, a manufacture of urethane was chosen (PSI Urethanes Inc.) because they could formulate the urethane and cast it to our dimensions. A purchase order was given to PSI Urethanes Inc and the following springs were purchase: 


\begin{tabular}{|c|c|}
\hline \multicolumn{2}{|c|}{ Procured Springs by PSI Urethane } \\
\hline $\begin{array}{c}\text { Spring Shore } \\
\text { Hardness } \\
\text { (Durometer A) }\end{array}$ & 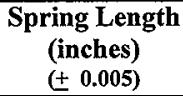 \\
\hline 30 & 1.00 \\
\hline 30 & 1.125 \\
\hline 30 & 1.25 \\
\hline 30 & 1.375 \\
\hline 40 & 1.00 \\
\hline$\overline{40}$ & 1.125 \\
\hline 40 & 1.25 \\
\hline 40 & 1.375 \\
\hline
\end{tabular}

Springs have an outside diameter of 1.63 inches $( \pm 0.005)$ and an inside diameter of 0.87 inches $( \pm 0.005)$.

These springs will undergo testing to evaluate which ones will last the longest and thus meet the requirements set forth in this document.

\subsubsection{Sketches/Drawings}

All graphical depiction can be found in Appendix A.

\section{Drawing 1}

This is a drawing of the stinger tool and its associated Bill of Material. GEC Alsthom has provided the drawing. The drawing number is 101-3737.

\subsection{Verification of Product Design}

All equipment developed will be verified by either having an independent review, test specification, or calculations. Appendices C and D show test specifications and testing reports. 


\section{Design Package for Fuel Retrieval System \\ Fuel Handling Tool Modification}

January 28, 1999

\subsubsection{Analysis}

\subsubsection{Calculations}

Developmental calculations can be found in Appendix B.

In addition to the research for the spring material, a finite element model of the spring was developed using ANSYS\&. Good results were not attainable because it was too difficult to get actual physical properties of the urethane. This calculation was not included in the document.

Another calculation was preformed that solved for the minimum required force/pressure the spring must exert on the inner diameter of an element in order for the element to be lifted. This calculation was conservative in that it used a reliability factor of 2 and assumed an outer element weighed $50 \mathrm{lbs}$.. This calculation along with its results can be found in Appendix B.

\subsubsection{Testing}

Testing was performed to determine if the PSI springs would work better than the Schilling supplied springs. Several tests were done to evaluate the springs. A test specification was written to describe the process of evaluations used to make the determination. This specification can be seen in Appendix C.

Results from the tests performed have been reported in Appendix $\mathrm{D}$ and its associated pictures are in Appendix E. Test results showed that the spring design would not work. The reasons are as follows:

1. The springs can not exert enough force on the side of the wall of an element to sustain the weight of an element.

2. The fuel retrieval tool can only exert about $250 \mathrm{lbs}$. or less of compressive force to a spring, which is not enough to accommodate the difference in internal diameters. 


\section{Design Package for Fuel Retrieval System Fuel Handling Tool Modification}

January 28, 1999

HNF-3526 Rev. 1

Page 8

3. The Schilling supplied springs worked during the Konan training test conditions but failed during the test conditions applied through this design package. The failure was attributed to a difference of pipe diameter and surface finish between the training test pipes (dummy fuel elements) and the pipes used in this design package test. The design package test used the worst case conditions. These conditions utilized a pipe with the internal diameter set to the largest recorded design and contained a smooth surface. The training test elements had the best conditions such that the internal diameter of the pipes were based on the smallest recorded design and had a rough surface finish due to rust.

\subsection{Turn Over of Product}

\subsection{Final Design Description}

There is no final description for the elastomer spring design. Modification of the spring design for the fuel retrieval tool showed the overall design to not fully meet the specifications.

\subsection{Path Forward}

It was determined to stop modification work on the elastomer spring design and proceed with a new concept for the entire tool. The new concept shall meet all the previous operational requirements listed in this document with the exception of those pertaining to the use of an elastomer spring. Use of the existing actuator block is preferred because Operations likes the ease of its removal in case of a failure. This document will be changed to show the new concept(s) and associated testing there in. 
Design Package for Fuel Retrieval System

Fuel Handling Tool Modification

January 28, 1999

HNF-3526 Rev. 1

Page 9

Appendix A

Graphical Depictions of Product 


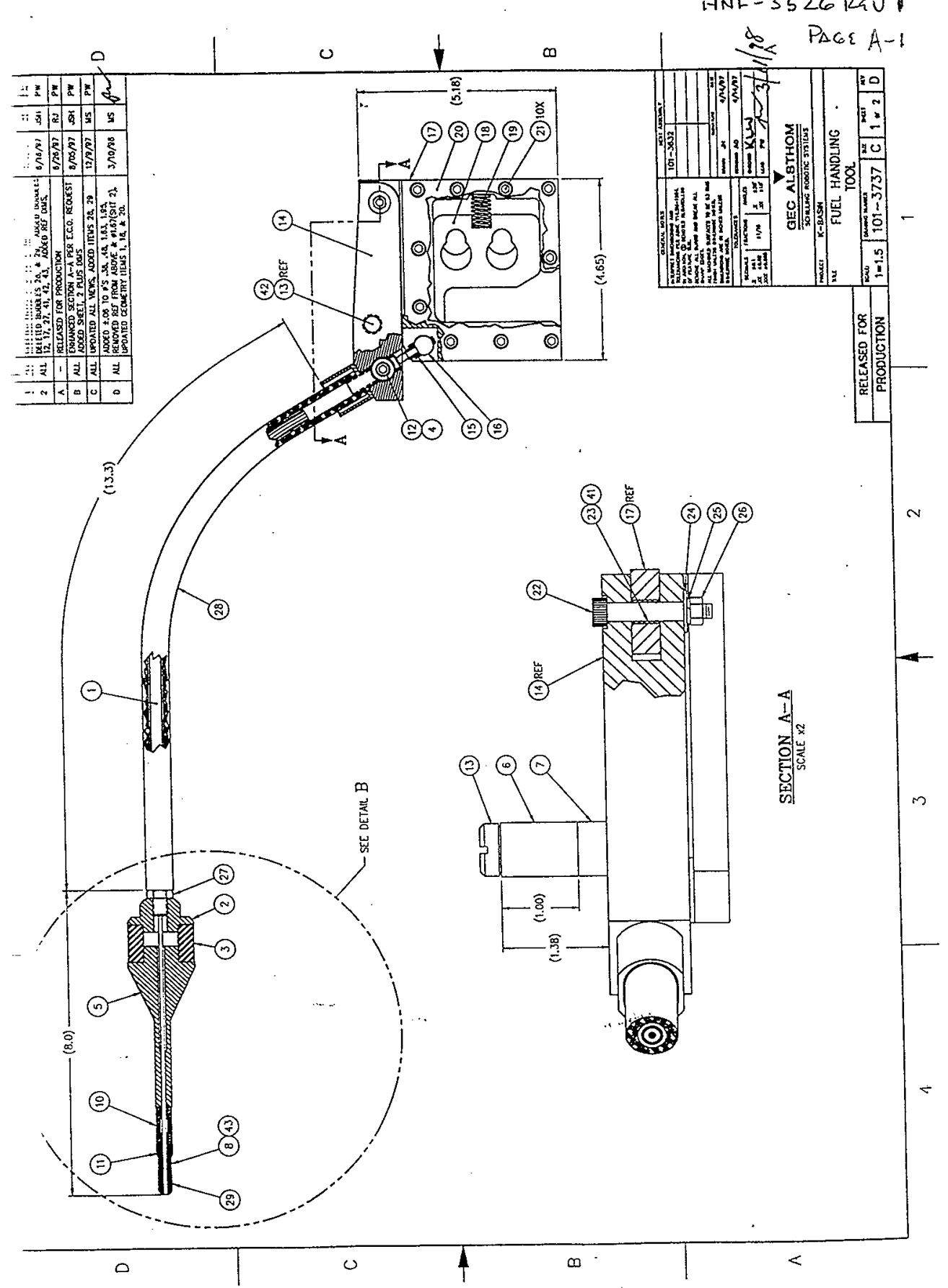




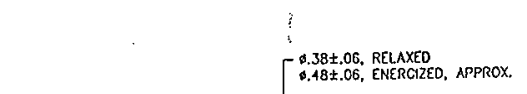

B

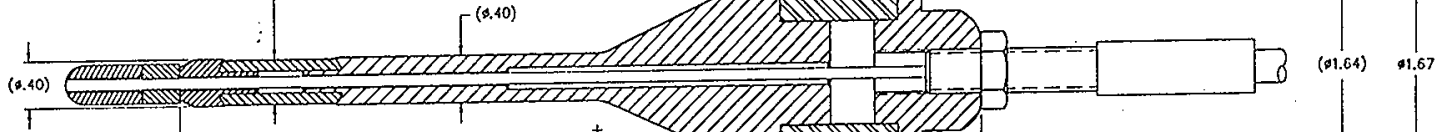

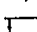

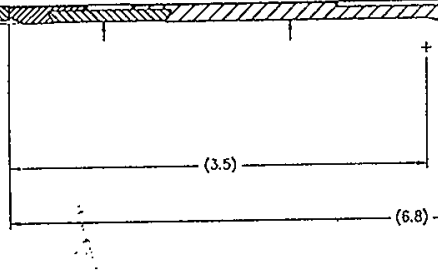

$+$

A 
software, Inc.

$=4$

20

.5737
Schilling Robotic Systems, Inc. MANUFACTURING BON WITH LABOR AND PROCESS
PACE $A-3$ $05 / 11 / 98$

Page 1
-.
Rev $L T$

Description TCOL, FUEL HANDLING
Group PFC Comodity Clase Planner auyer Drawing $\mathrm{KB}$

7062

A Pr

$01 \quad \$ 3737 C 2 D$
D 4

\section{$\exists$}

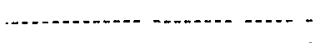

$: 2-1750$

$\because \approx-4882$

$: 2-1727$

$: 3-0240$

$: 3-0244$

$: 2-1775$

$: 1-4900$

$: 1-5037$

$\vdots-4888$

$: 2-4889$

$: 7.0367$

$: 1-4891$

$: 1-4892$

$: 1-4893$

$: 9-4894$

;2-1729

$:=-4895$

$: 2-0186$

$: 2-1728$

$: 3-0223$

$: 2-1163$
REV CL IT

CARLE, FIEX

D $R \quad 20$

A $\mathrm{R} \quad 30$

R 15

SPRING, URE

SCREN, SBT, 20-32 X 2/4,326 R 15

SS, HEX DRIVE

BODY, FUEL HANDEING

B $R \quad 30$

BUSHING, SLEEVE, $23 / 32$ OD $X \quad R \quad 30$

$5 / 8$ ID $x$ 1, IGLIDE T500

EUSHING, SLEEVE, 23/32 OD $X \quad R \quad 30$

5/8ID X 3/8, IGLIDE

STOP SLEEVE, 3/32, COPPER R 20

GRIPPER, URETHANE, INFER EL B $R \quad 45$ EMENT

GUIDE, INSERTION

B $\quad$ R 30

CABLE END, MOUNTING SIDE $B$ R 30

PIN, ARM, ACTUATOR

B $R \quad 30$

ARM, ACTUATOR

A $\quad \mathrm{R} \quad 30$

IOCKNUT, CABLE

A $\mathrm{R} \quad 30$

A $\quad$ R 30

D $\mathrm{R} \quad 30$

BODY, TOOL MOUNTING

PLATE, LOCK, TOOL MOUNTING C R 30

SPRING, .5000 $\times 1.44 \mathrm{~L}, \mathrm{SS}, \mathrm{C} \quad R \quad 35$

ENIURY S-1292

PLATE, COVER, TOOL MOUNTIKG A R 30

SHCS, $1 / 4-28 \times 3 / 4$, SS

R 15

SCREH, SHOULDER, 3/4 X 1 LG $\mathrm{R} 15$

SS

BUSHING, SLEEVE, 5/26 OD $X$ R 20

$1 / 4$ ID $X 3 / 8$ LG

WHSHER, FLAT, $\# 20, .438$ OD,5 R 5

$\$$
QUANITY U/M REEERENCE

MLT BEGIN END

$1.00 \mathrm{EA}$

Yeg

$1.00 \mathrm{EA}-$

Yes

$1.00 \mathrm{EA}=$

Yes

$2.00 \mathrm{EA}-$

Yes

$1.00 \mathrm{EA}-$

Yes

$1.00 \mathrm{EA}-$

Yes

$1.00 \mathrm{EA}-$

Yes

$1.00 \mathrm{EA}-$

Yes

$1.00 \mathrm{EA}$

Yes

$2.00 \mathrm{EA}-$

Yes

$1.00 \mathrm{EA}=$

Yes

$1.00 \mathrm{EA}=$

Yeg

$1.00 \mathrm{BA}=$

Yes

$3.00 \mathrm{EA}-$

Yes

1.00 EA - Yes

1.00 EA - Yes

$1.00 \mathrm{EA} \mathrm{-} \mathrm{Yes}$

$2.00 \mathrm{EA}$ - Yes

$1.00 \mathrm{EA}-\quad$ Yes

$10.00 \mathrm{EA}-\ldots . . \quad$ Yes

2.00 EA - Yes

$1.00 \mathrm{EA}-\quad$ Yes

$2.00 \mathrm{EA}$ - Yes 
FEtware, Inc.

$$
\text { =ㄴ }
$$

Description

$\$ 737$ TOOL, FUEL HAWDLING

=kage Factor: 0.00
Schilling Robotic Systems, Inc. MANUFACTURING BOM WITH LABOR AND RROCESS
Page A-4

$05 / 11 / 98$

Page 2

-

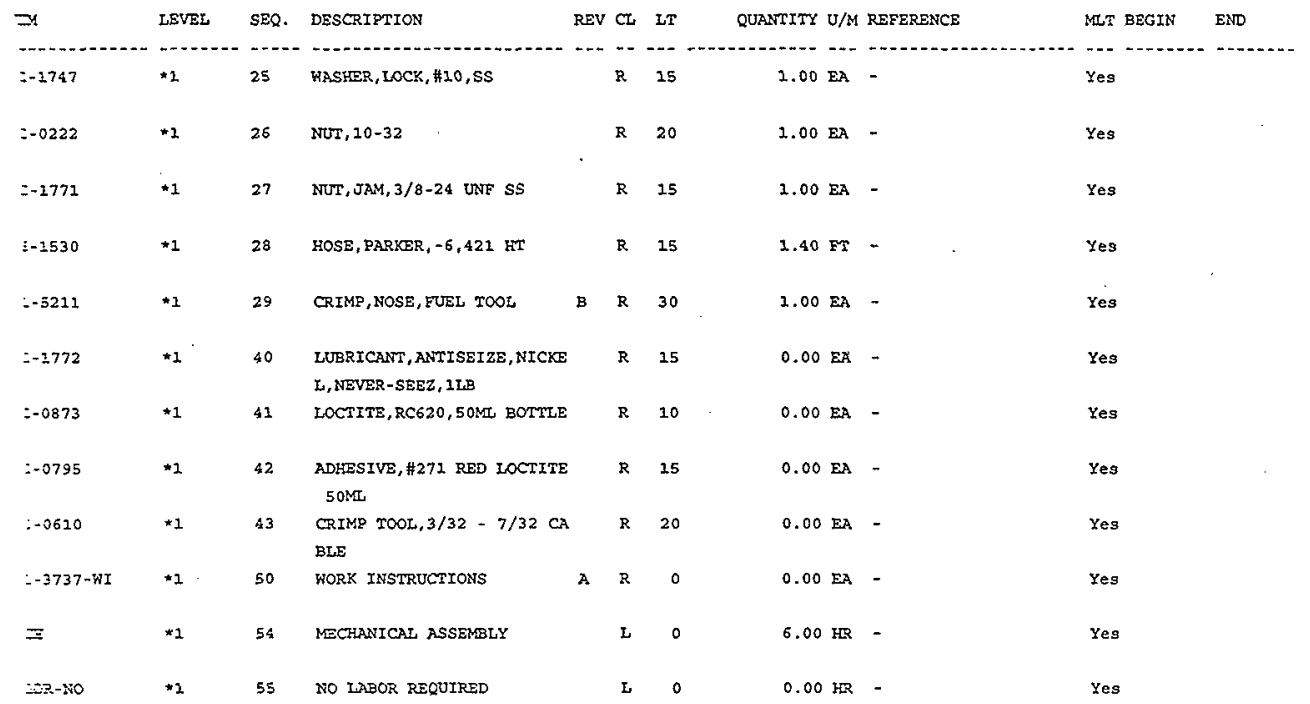

- ative Lead rime for 101-3737 = 49 
Design Package for Fuel Retrieval System Fuel Handling Tool Modification

January 28, 1999

HNF-3526 Rev. 1

Page 10

Appendix B

Calculations 
Calc. No 65100301-001.

Revision 0

Page 1 of 3

DESIGN CALCULATION

Client : Duke

WolJob No 65100301

Subject : Lifting Fuel Rods With CONAN Stinger

Location: $100 \mathrm{KBasin}$

Date

By David J.Tedeschi

Checked

By

Revised

By

GIVEN:

Inside radi for outer and inner fuel rods

$r_{\text {outer }}:=0.889$ in
Weight of fuel rod length of spring rod

$\mathrm{w}_{\text {rod }}:=50$ lbf $\quad H:=1,1.125 . .1 .375$

$\mathrm{H}$ in

1

1.125

1.25

1.375

PROBLEM: An elastomer spring is inserted into fuel rod and expanded. Once expanded, the rod can be lifted. Solve for the required pressure the elsatomer spring must exert on the inner surface wall of the fuel rod in order to lift an outer fuel rod.

SOLUTION: The weight of a fuel rod is equivalent to what the required force is to lift the fuel rod. The coefficient of resistance which keeps the spring from slipping when the rod is lifted is unknown as well as the resistant force due to moving the rod through the water. Therefore a factor of reliability of 2 will be applied.

The following diagrams illustrate the problem:

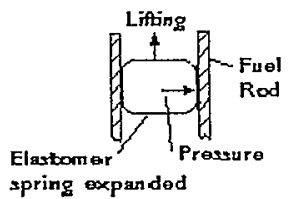

\section{FREE BODY DIRGRAM}

$\therefore \cdots$

11

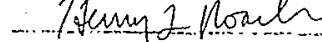
$10 / 24198$

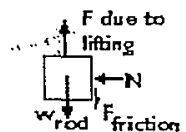


Calc. No 65100301-001.

Revision 0

Fluor Daniel Northwest

Page 2 of 3

\section{DESIGN CALCULATION}

Client : Duke

Subject : Lifting Fuel Rods With CONAN Stinger

Location: $100 \mathrm{~K}$ Basin
WO/Job No 65100301

Date

By David J.Tedeschi

Checked

By

Revised

By

Solve for the minimal normal force $N$ that the spring needs to apply in order to keep the spring from slipping when a lifting force of $50 \mathrm{lbs}$ or greater is applied.

$\mathrm{N}=$ the normal force applied from the spring to the wall

Assume $\mu$ (coefficient of friction) based on rubber against steel: $\mu:=0.36$

Ref. Engineering Mechanics Vol 1 Statics, J.L. Meriam, pub. John Wiliey and Sons

Frictional force is equal to the weight of the fuel rod.

$$
\begin{aligned}
& F_{\text {friction }}:=\mathrm{w}_{\text {rod }} \\
& N:=\frac{F_{\text {friction }}}{\mu} \\
& N=138.889
\end{aligned}
$$

Apply a Factor of Reliability: $\quad \mathrm{R}:=2$

The required force for the elastomer spring to exert against the wall is:

$$
\begin{aligned}
& \mathrm{F}_{\text {required }}:=\mathrm{N} \cdot \mathrm{R} \\
& \mathrm{F}_{\text {required }}=277.778 \mathrm{lbf}
\end{aligned}
$$

Solve for the pressure needed to be applied:

Assume the elastomer spring surface area contacts the wall of the rod by the following dimensions:

Although the outside radi of the spring is .407 , the inside radi of the tube will be used since it is the dimension the spring must be to apply pressure.

$$
C_{\text {outer }}:=2 \cdot \pi \cdot r \text { outer }
$$

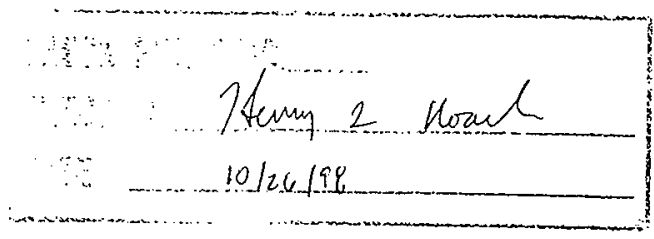


Calc. No 65100301-001

Revision 0

Page 3 of 3

\section{DESIGN CALCULATION}

\begin{abstract}
Client : Duke
Subject : Lifting Fuel Rods With CONAN Stinger

Location : $100 \mathrm{KBasin}$
\end{abstract}

WO/Job No 65100301

Date By

Checked

Revised

By
David J.Tedeschi

Surface area of spring $\quad \mathrm{A}(\mathrm{H}):=\mathrm{H} \cdot \mathrm{C}_{\text {outer }}$

\begin{tabular}{|l|}
\hline A(H) in $^{2}$ \\
\hline 6.586 \\
\hline 6.284 \\
\hline 7.982 \\
\hline 7.68 \\
\hline
\end{tabular}

Percentage of actual area applied to wall due to bulge is $10-30 \%$.

$$
\mathrm{P} 10 \%:=.1 \quad \mathrm{P} 20 \%:=.2 \quad \mathrm{P} 30 \%:=.3
$$

Applied area $\mathrm{A}_{\text {ap } 10}(\mathrm{P} \%, \mathrm{H}):=\mathrm{P} 10 \% \cdot \mathrm{A}(\mathrm{H}) \mathrm{A}_{\text {ap } 20}(\mathrm{P} \%, \mathrm{H}):=\mathrm{P} 20 \% \cdot \mathrm{A}(\mathrm{H})$

$$
A_{\text {ap } 30}(P \%, H):=P 30 \% \cdot A(H)
$$

\begin{tabular}{|c|c|c|}
\hline $\mathrm{A}_{\text {ap } 10}(\mathrm{P} 10 \%, \mathrm{H}) \mathrm{in}^{2}$ & $\mathrm{~A}_{\text {ap20 }}(\mathrm{P} 20 \%, \mathrm{H})$ in $^{2}$ & $\mathrm{~A}_{\text {ap } 30}(\mathrm{P} 30 \%, \mathrm{H}) \mathrm{in}^{2}$ \\
\hline 0.559 & 1.117 & 1.676 \\
\hline 0.628 & 1.257 & 1.885 \\
\hline 0.698 & 1.396 & 2.095 \\
\hline 0.768 & 1.536 & 2.304 \\
\hline
\end{tabular}

Required pressure spring needs to apply for to prevent slipping at spring lengths of $\mathrm{H} 10$ to $30 \%$ surface contact:

$$
\begin{aligned}
& P_{10}(H):=\frac{F_{\text {required }}}{A_{\text {ap } 10}(P 10 \%, H)} \quad P_{20}(H):=\frac{F_{\text {required }}}{A_{\text {ap } 20}(P 20 \%, H)} \quad P_{30}(H):=\frac{F_{\text {required }}}{A_{\text {ap } 30}(P 30 \%, H)}
\end{aligned}
$$

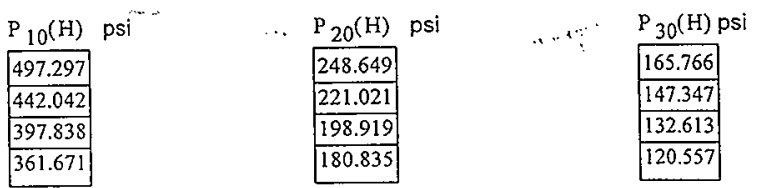


Design Package for Fuel Retrieval System Fuel Handling Tool Modification

January 28, 1999

HNF-3526 Rev. 1

Page 11

\section{Appendix C}

\section{Test Specifications}




\section{FRS Test Specification For The Evaluation of}

The Fuel Handling Tool's

Large Elastomer Spring

HNF-3526 Rev. 1

December 7, 1998

1.0 PURPOSE

Documant contrallap ondzr Red line methed By Dau id TeDESCHI

The purpose of this test specification is to evaluate the use of different elastomer springs for the fuel handling tool (referred to as the stinger). These evaluations will concentrate on the large diameter spring. All evaluations listed will be done through testing. Each evaluation must be done before proceeding to the next one. The following is the sequential list of evaluations that describe the purpose for each test:

\section{Evaluation - 1}

The first evaluation will be to find the force the fuel handling tool lever arm can exert when the Konan hand is opened. This test is needed in order to determine what the compressive force will be on the spring.

\section{Evaluation-2}

The second evaluation will be to determine the surface area and the resultant force associated with the expansion/bulging of an elastomer spring when it is compressed by the same force obtained through the first evaluation. The spring's surface area that contacts the inside diameter wall of an outer fuel element due to expansion will be measured along with the force it exerts on the wall. This evaluation will help determine which spring applies the most surface contact and force to an inner element wall. The importance of this test is will be that it will verify the calculated required force the spring must exert against the wall in order to keep it from slipping when the element is lifted. This evaluation will test eight springs manufactured by PSI Urethane and should narrow down the choices to at least two.

\section{Evaluation - 3}

The third evaluation will be to determine how much force it will take to remove a spring compressed from a simulated fuel rod under wet and dry conditions. This test will determine the effect water has on the spring's ability to lift an element without slipping.

\section{Evaluation - 4}

The forth evaluation will be to install a spring on an actual fuel handling tool and let the K-Basin Operators train with it for at least a month. This evaluation will determine a spring's ability to function under normal operating conditions. This evaluation will use the best two springs from Evaluation 3. 
Pagec2

\subsection{TEST DESCRIPTION}

All evaluations and visual observations will be recorded in a test log and assembled in a test report. Evaluations and observations will be logged in section 8.0 of this document. Pictures will be taken as necessary. This document and final test report will be incorporated into HNF-3526, Design Package For Fuel Retrieval System Fuel Handling Tool Modification upon completion of testing.

The following are descriptions of each evaluation test:

\section{Evaluation -1}

A stinger tool will be modified to remove the springs and the wire rope. A new wire rope (with a plug on one end) will be attached to the lever arm through the hole on the lever. The lever arm assembly is then placed on the Konan. The Konan arm will then be placed at a $90^{\circ}$ such that it is parallel with the table. The arm will be braced to keep it from moving during the test. The other end of the wire rope will be attached to a force gauge (dynamometer) that will be firmly supported. A preload will be applied to the rope enough to keep it taunt. See sketch for evaluation 1 test setup.

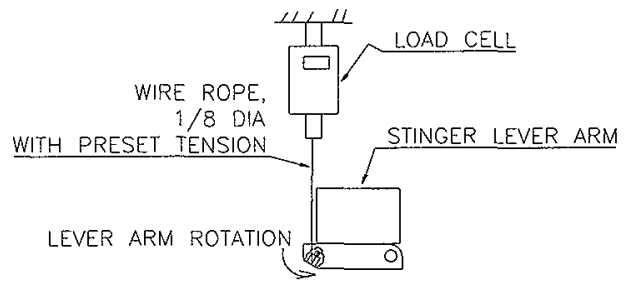

Sketch of Evaluation 1 test setup

The Konan hand will be opened and lever arm will apply a force on the wire. A reading on the force gauge will be made. The Konan hand will be released, reopened, and another reading will be taken from the gauge. This procedure will be done 3 times and the average force will be used for the next evaluation.

\section{Evaluation -2}

A testing apparatus is constructed to hold a spring in place during testing. The apparatus is secured on the SATEC machine and the load cell is installed in the small hole of the test apparatus. An insert is placed in the large hole of the 
HNF-3526 Rev. 1

December 7, 1998

Page $s$

apparatus to help raise the spring in order to align its mid point with the center line of the load cell hole.

The sketch shown below describes the spring test setup.

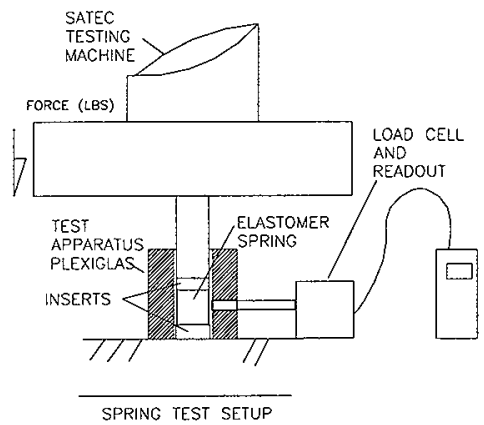

Sketch of Spring Test Setup

One of the eight springs is then placed in the large hole. A second insert is then placed on top of the spring and $500 \mathrm{lbs}$. or the force obtained from Evaluation 1 is applied to the spring using the SATEC machine. The amount of spring material touching the test apparatus wall is measured with a ruler and the force that the spring exerts against the wall is measured using the load cell. This procedure is repeated for all 8 springs.

\section{Evaluation -3}

Evaluation 3 will test two of the best springs from Evaluation 2. A spring will be installed to a compression device. The spring and compression device is then inserted into a hole bored in a steel block. The hole in the block is the same diameter as the inner diameter of an outer fuel element. The spring is then compressed to the amount determined by Evaluation 2 . The block is then firmly attached to the Satec under the lifting head. Lastly, the compression device is then attached to the Satec lifting head and the lifting head will rise attempting to pull the spring out and the force applied is monitored. See sketch below for layout of test and attached sketch titled Spring Test Setup For Evaluation 3 for details. The pulling operation will be applied until the compression device/spring comes out or until $500 \mathrm{lbs}$ is reached. This procedure is repeated with water sprayed on 
FRS Test Specification For The Evaluation of

The Fuel Handling Tool's

Large Elastomer Spring

HNF-3526 Rev. 1

December 7, 1998

Pagec4

the contact surface between the spring and block. The test will be repeated for the remaining spring as well.

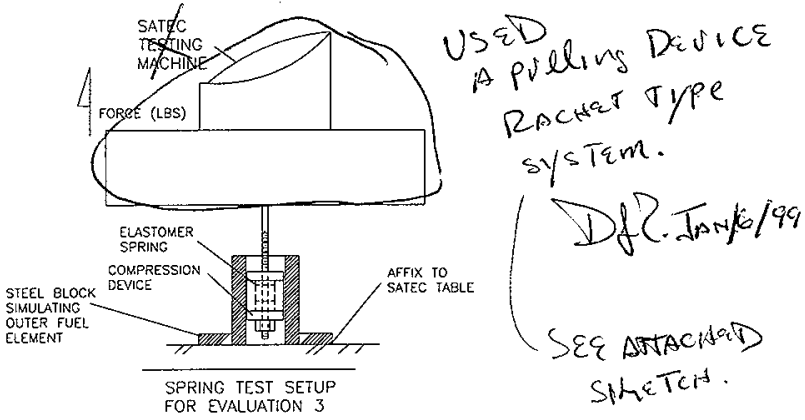

Evaluation - 4

This test will be an operational test of the two chosen springs from Evaluation 2. A spring will be installed in a stinger tool and used during training for one to three months.

\subsection{CONDITIONS FOR TESTS}

Testing will be done in the 305 facility located in the Hanford 300 Area. The facility's SATEC testing machine will be required.

\subsection{REQUIRED SUPPORT}

\subsection{MANAGEMENT OF TEST}

Fluor Daniel Northwest Engineer will be responsible as the test engineer. Numatec will be responsible for providing support to testing through technician support. This support will include fabrication, erection, and minor operations of the testing apparatus. K Basin Operations will provide Konan operating support.

This document will not be incorporated into HNF-3526 until completion of Evaluation 3. A master copy of this document will be used for testing and will be controlled by the test engineer. Changes will be made only by the approval of the test engineer using red-lines, their signature, and date of change.

\subsection{EQUIPMENT}


- 8 Springs purchased from PSI Urethane

- $\quad$ Stinger tool and it wire rope.

- Test apparatus shown in sketches

- Load cell and read out

- $\quad$ SATEC testing machine

- Water enough cover a dummy fuel element

- Digital or film based camera

- Konan robotic arm

- Miscellaneous support tools (hammers, screw drivers,...)

\subsection{ACCEPTANCE CRITERIA AND DATA REQUIRED}

\section{Evaluation - 1}

Vendor data shows that the normal wire rope will break at approximately 1000 Ibs. and the crimp on its end will fail around $800 \mathrm{lbs}$. A design goal is to determine if the Konan will be able to apply at least half of this force ( $400 \mathrm{lbs}$.) when it's hand opens. There is no acceptance criterion. What is important is to discover what force the hand actuator can exert on the lever arms.

\section{Evaluation - 2}

This test should determine at least two of the eight springs that will apply the greatest force with the most amount of spring material touching the wall when compressed. These two acceptance parameters will provide for the greatest reliability to lift an element.

\section{Evaluation - 3}

Acceptance of this test will be if the two chosen springs from Evaluation 2 will not come free of the test block when a lifting force of $50 \mathrm{lbs}$. to $100 \mathrm{lbs}$. is applied under dry and wet conditions.

\section{Evaluation - 4}

Acceptance of this test will be if the spring can maintain its function without adjustment for an operating period of at least one month.

\subsection{SAFETY AND PRECAUTIONS}


FRS Test Specification For The Evaluation Of

The Fuel Handling Tool's

Large Elastomer Spring

HNF-3526 Rev. 1

December 7, 1998

Pagec6

Care should be taken when handling cable. Cable may have sharp ends, which can easily penetrate a person's skin. Weights as well as the dummy fuel element can be $50 \mathrm{lbs}$. or greater and mechanical methods should be considered as appropriate when handling.

\subsection{TEST PREDICTIONS}

It is expected in Evaluation 1 that Konan lever hand when actuated will be able to apply at least $400 \mathrm{lbs}$ to the springs. Out of the eight springs tested, it is expected from Evaluation 2 that the softer shortest springs will compress best and thus give the greatest force with the most material touching the wall. It is expected from Evaluation 3 that the best two springs chosen should be able to with stand a lifting force of $50 \mathrm{lbs}$. under dry conditions but under wet conditions, there is a good chance one of them could fail. It is expected from Evaluation 4 that the long term testing will show that adjustments will still need to be made. The long-term test will be skewed in that it will be done with dry elements. However, if the springs fail in dry conditions, they most definitely will fail under wet conditions since the water can act as lubricant between the element wall and the spring. 
FRS Test Specification For The Evaluation of The Fuel Handling Tool's Large Elastomer Spring HNF-3526 Rev. 1

December 7, 1998
ORIGINAL

Page $<-7$

8.0 OBSERVATIONS

Evaluation 1

Date of test: $12 / 6 / 98^{-10: 30 \mathrm{sm}}$ Technician:

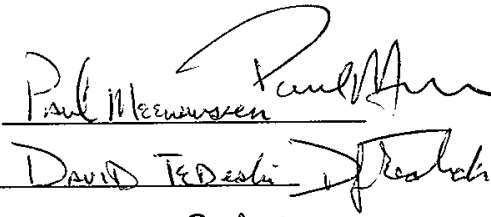
$12 / 9 / 98-8: 57 \mathrm{Am}$ Engineer:

Pie load

\begin{tabular}{|c|c|c|}
\hline \multirow{2}{*}{ Test } & \multicolumn{2}{|c|}{$\begin{array}{r}\text { Dynamometer Readings } \\
\text { lbs. }+(T / 6 / 400 \times b\end{array}$} \\
\cline { 2 - 4 } & Initial Reading & Final Reading \\
\hline 1 & $51-60$ & 163 \\
\hline 2 & 100 & -110 \\
\hline 3 & & \\
\hline
\end{tabular}

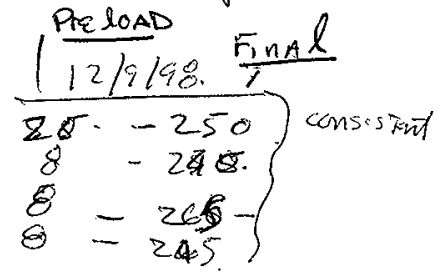

Notes:

Dynafor calzone 750-25-06-004 exp 3-4-79.

- Ado a larger diameter ac Evaluation 2- A rim.

Date of test: $\frac{12 / 17 / 98}{10: 38 \mathrm{Am}}$

Technician: Dowouce $02 R$

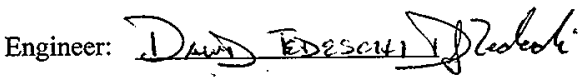

stack

Pipe COPTUNOD,

$$
9
$$

8

8

original

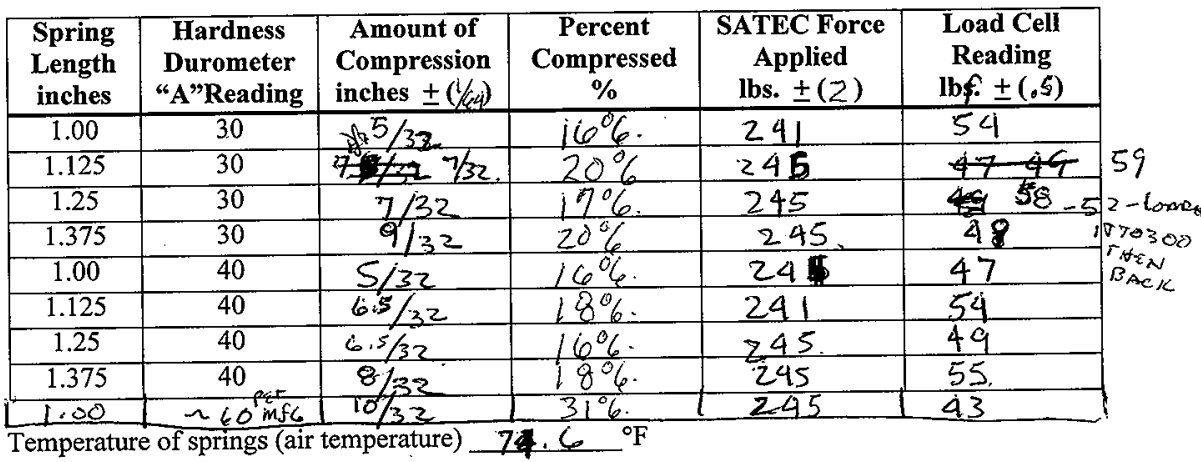

Notes:

IH Dentation were obsserab an springs after compression. Indentations were it LOADCEll Arm faCE AND inTERhaldiAmeter from SPring Holders

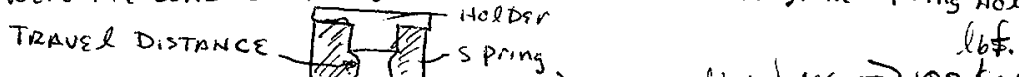

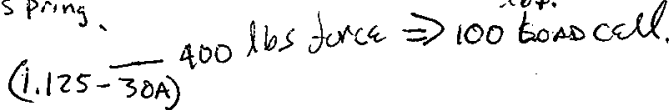


HNF-3526 Rev. 1

December 7, 1998

Page $C-8$

Evaluation 3

Date of test: $12 / 29 / 28$

Technician: Don Parill Dizoucll

Engineer: David TEDSx+1 Y Dedesh.

Air Temperature: ${ }^{\circ} \mathrm{F}$

Water Temperature: : $28^{\circ} \mathrm{C}$ ${ }^{\circ} \mathrm{F}$ D.silfie watar. Peionzido.

\begin{tabular}{|c|c|c|c|c|c|c|c|}
\hline \multirow{3}{*}{$\begin{array}{l}\text { Spring } \\
\text { Length } \\
\text { (inches) }\end{array}$} & \multirow{3}{*}{ 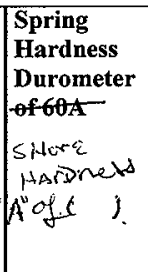 } & \multicolumn{3}{|c|}{ Dry Conditions } & \multicolumn{3}{|c|}{ Wet Conditions } \\
\hline & & & & & \multicolumn{3}{|c|}{ Nejir RAN } \\
\hline & & \begin{tabular}{|l} 
Applied \\
Force of 50 \\
lbs. \\
(Pass/Fail)
\end{tabular} & $\begin{array}{l}\text { Applied } \\
\text { Force of } \\
100 \mathrm{lbs} \text {. } \\
\text { (Pass/Fail) }\end{array}$ & $\begin{array}{l}\text { Applied } \\
\text { Force at } \\
\text { Failure } \\
\text { (lbs.) }\end{array}$ & $\begin{array}{l}\text { Applied } \\
\text { Force of } 50 \\
\text { lbs. } \\
\text { (Pass/Fail) }\end{array}$ & $\begin{array}{l}\text { Applied } \\
\text { Force of } \\
100 \text { Ibs. } \\
\text { (Pass/Fail) }\end{array}$ & $\begin{array}{l}\text { Applied } \\
\text { Force at } \\
\text { Failure } \\
\text { (lbs.) }\end{array}$ \\
\hline 1,125 & 30 & $\begin{array}{l}10 \cdot P \\
23-F \\
2\end{array}$ & $\begin{array}{l}20-1 \\
25-F=\end{array}$ & & & & \\
\hline 1.23 & 30 & & & & & & \\
\hline
\end{tabular}

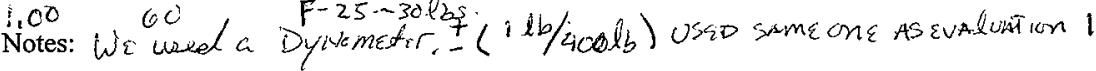
30-lx org wall- faileal.

- Sprngs werg lopded in to Tomprzasion device, then compresidel

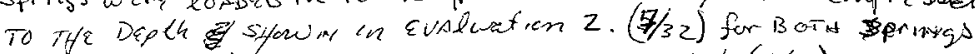
Teste $D$, Except for tate original unichwai compristed (10/32) is

Evaluation 4 - Springs were pilled out, at 20 - 30 lbs. Fitisilvat Acoptable. since $\varepsilon$ lemento wieoght is $35-55$ lbs.

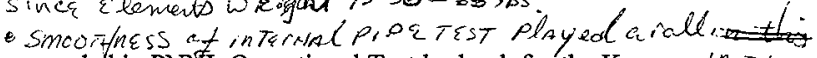

This information will be recorded in PNNL Operational Test logbook for the Konan. In Ttfe spor $n_{j}$ Results will be added in at a later date. cerming out.

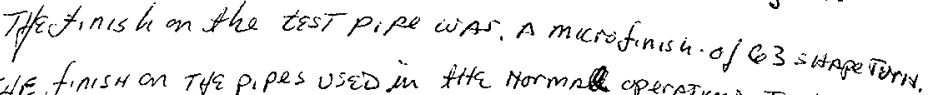

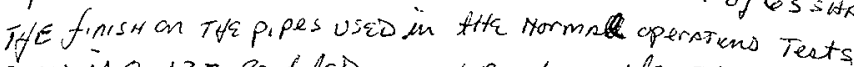

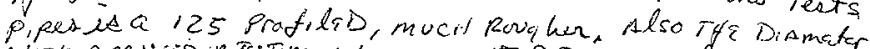

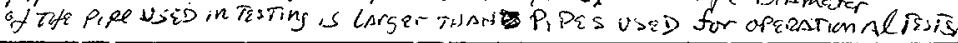


FRS Test Specification For The Evaluation Of

The Fuel Handling Tool's

Large Elastomer Spring

HNF-3526 Rev. 1

December 7, 1998

ORIGINAL

Page $C-9$

$k N$

9.0 ATTACHMENTS

Sketches

original ID of spring.

1.720 - Grand To 1 . Pipe finish

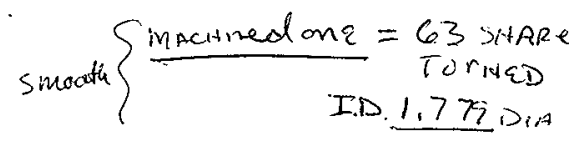

Application

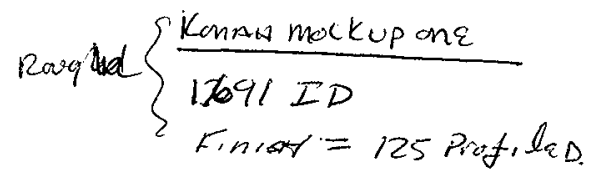

Evaluation 2 repents

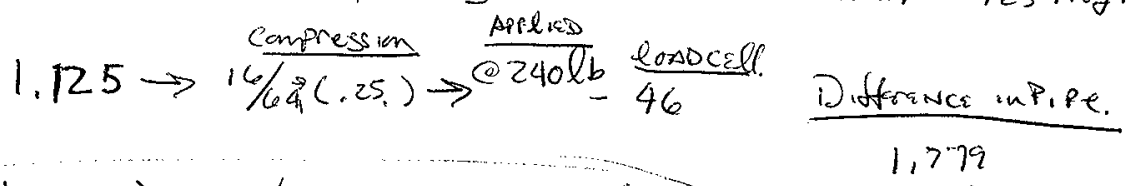

$$
\begin{aligned}
& 1.00 \rightarrow 20 / 64 \rightarrow(.3125)-244-49 \longrightarrow \frac{-1.621}{.088}
\end{aligned}
$$$$
1.375 \rightarrow \frac{3}{6}(-375) \quad 244-35
$$

TEST 3/cualuation 3

USED I"Diamater in Pull Test.

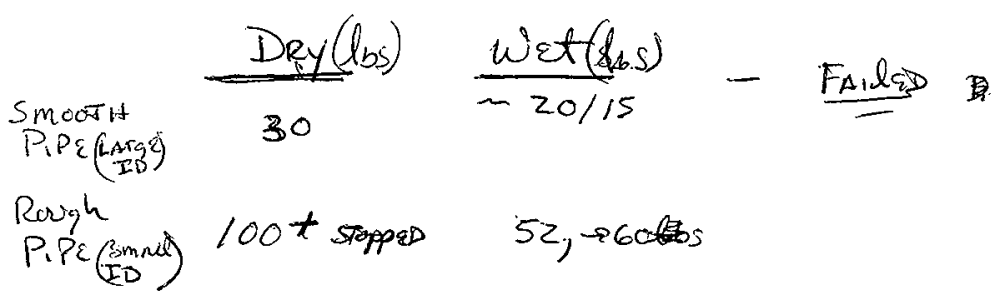



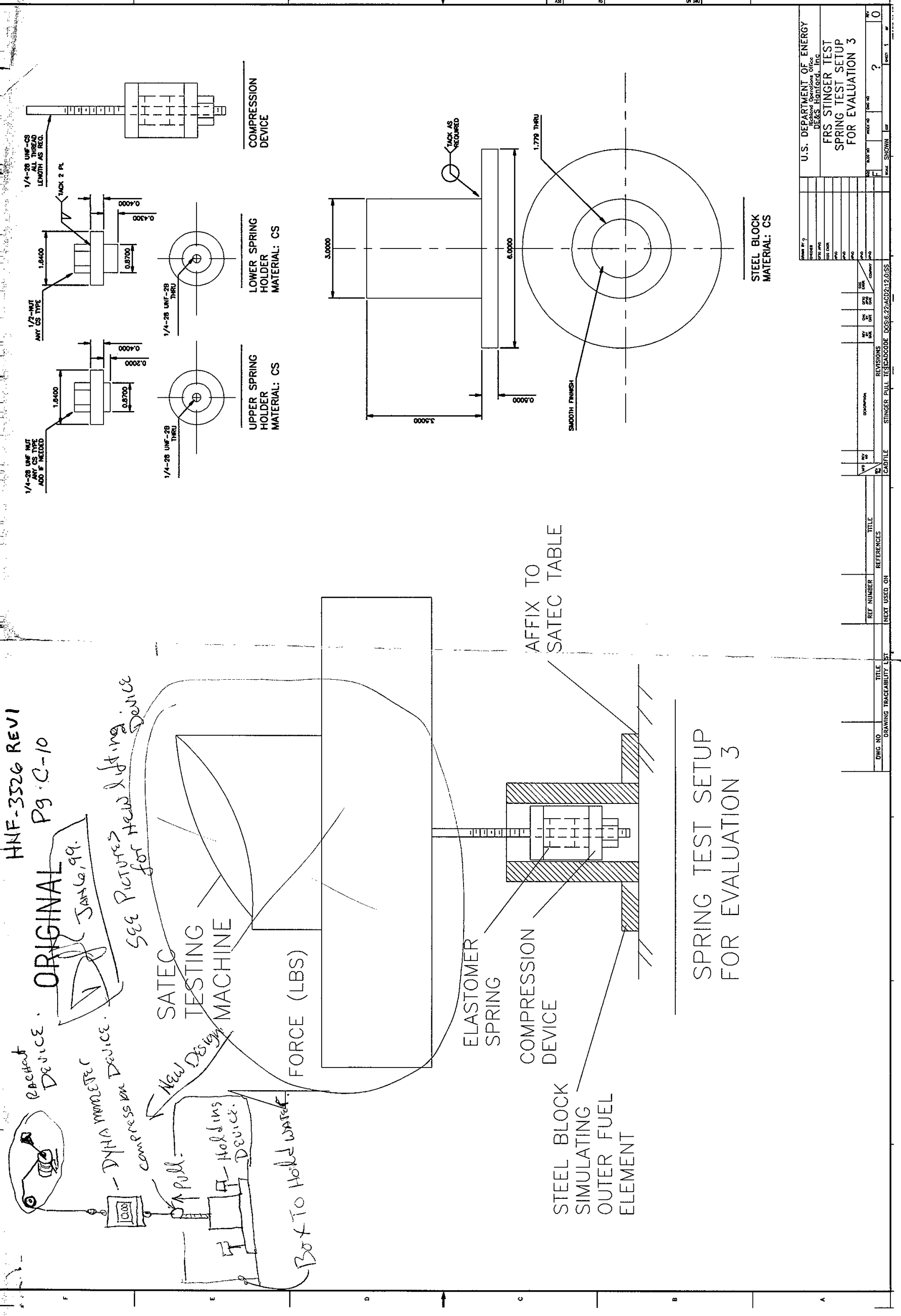
Design Package for Fuel Retrieval System

Fuel Handling Tool Modification

January 28, 1999

HNF-3526 Rev. 1

Page 12

\section{Appendix D}

Test Report 


\section{FRS Test Report For The Evaluation Of \\ The Fuel Handling Tool's \\ Large Elastomer Spring}

HNF-3526 Rev. 1

January 28, 1999

\subsection{Purpose}

The purpose of this test report is to document the three evaluations performed on nine elastomer springs. Results from Evaluation 1 determined the amount of force Konan will exert on a spring. Results from Evaluation 2 determined the amount of compression a spring will have and sidewall force it applies when the force from Evaluation 1 is applied. Results from Evaluation 3 show what force is required to pull the spring out of an element sized to the worst conditions. For details on why the evaluations are being done, see the test specification in Appendix $\mathrm{E}$ of this document HNF3526 .

\subsection{Evaluation 1}

\subsection{Results}

\subsubsection{Setup}

A fuel retrieval tool was modified by removing everything off of it except for the portion that attaches to the Konan arm. Next, a wire rope was attached through the fuel retrieval tool lever arm hole. The other wire end was connected to a hanging dynamometer. The dynamometer was positioned directly above the lever arm in order to assure the maximum pull was measured. The Konan arm was supported to keep it from sporadic movement. A preload of no more than 5-10 lbs. was set on the rope. As the Konan hand would open, the wire rope would pull on the dynamometer and a load would be read. See pictures 1 through 4 in Appendix E for the setup.

\subsubsection{Testing and Data}

Testing showed that the Konan hand, when opened, can exert approximately $250 \mathrm{lbs}$. force $\pm 10 \mathrm{lbs}$. consistently on a spring. A preload of $25 \mathrm{lbs}$. was put on the wire and the jaws were opened. The first reading showed $250 \mathrm{lbs}$. on the dynamometer. The jaws were opened and the load on the wire returned to an $8 \mathrm{lb}$. preload. The jaws were reopened and the load again went to $245 \mathrm{lbs}$. This was repeated and the same preload of $8 \mathrm{lbs}$. was achieved and the final load was still $250 \pm 10 \mathrm{lbs}$.

\subsection{Problems}

The first time the test was preformed, erratic readings were obtained when the jaws opened. The hydraulic actuation produced difficulties in maintaining the arm steady and thus achieving a constant pull. This was overcome by using the another manipulator arm, placing the arm in a $90^{\circ}$ position, and resting it on wooden blocks. 
It was discovered that the Konan arm bar that engages with the fuel tool lever arm actuator, had to travel to far; thus not allowing for a full loading on the wire. It was also discovered that the bushings on the bar were not fully installed and this produced a lot of slop in the system. This slop added to the travel of the bar. The distance problem was over come by reinstalling the bushings on the bar using Locktite ${ }^{\mathrm{TM}}$ and increasing the diameter on the fuel pin. The following sketch depicts the diameter difference:

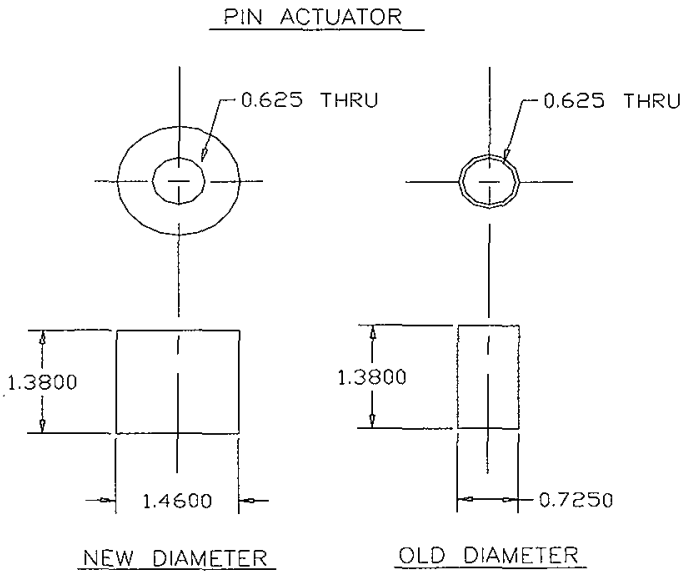




\section{FRS Test Report For The Evaluation Of \\ The Fuel Handling Tool's \\ Large Elastomer Spring}

HNF-3526 Rev. 1

\subsection{Evaluation 2}

January 28, 1999

\subsection{Results}

\subsubsection{Setup}

A frame test apparatus was built which firmly supported a load cell and clear Lexan tube. A long bolt was machined to the tube's internal diameter contour and was as the load cell actuator. The machining would account for overlapping of the spring when it was compressed. The tube and load cell were attached to the frame and spacers were added in the tube to adjust the springs height. The spacers would adjust the spring's height in order to position a spring's mid point height with the center of the load cell actuator. Force to a spring was applied using a machine made by Satec. A spring was loaded into tube and additional spacers were used to help apply the force evenly. A scale (readings are in $1 / 64^{\text {th }}$ of an inch) was placed such that it would measure the distance the Satec traveled. This Satec travel distance would equate to a spring's compression. The Satec had a read out that showed what real-time force it was applying. Pictures 5-13 in Appendix E show the test set up, springs tested, and the apparatuses used.

\subsubsection{Test}

Once a test apparatus was loaded with a spring, the apparatus would then be placed under the Satec platform. The Satec machine and load cell was zeroed. The Satec would slowly apply a force of over $260 \mathrm{lbs}$., then settle out at $240 \mathrm{lbs} .(+10,-0)$. A reading of the scale and load cell were made.

\subsubsection{Test Data}

The test data was tabulated in Table 1 and plotted in Graph 1. Results showed that the two best springs were the 1.125-inch long with a shore hardness of 30 , and the 1.25-inch long with a shore hardness of 30. It is interesting to note that the Schilling spring compressed the most and yet applied the least force. The 1.125 long spring with a shore hardness of 30 was compressed to $400 \mathrm{lbs}$. and gave a $100 \mathrm{lb}$. force reading on the load cell. 
FRS Test Report For The Evaluation Of

The Fuel Handling Tool's

Large Elastomer Spring

HNF-3526 Rev. 1

January 28, 1999

\begin{tabular}{|c|c|c|c|c|c|}
\hline \multicolumn{7}{|c|}{ Table 1 FRS Fuel Retrieval Tool Spring Test Results (Evaluation 2) } \\
\hline $\begin{array}{c}\text { Spring } \\
\text { Length } \\
\text { (inches) }\end{array}$ & $\begin{array}{c}\text { Hardness } \\
\text { (shore A) }\end{array}$ & $\begin{array}{c}\text { Compression } \\
\text { (inches) }\end{array}$ & $\begin{array}{c}\text { Percent } \\
\text { compression } \\
\text { (\%) }\end{array}$ & $\begin{array}{c}\text { Force applied } \\
\text { (Ibf) }\end{array}$ & $\begin{array}{c}\text { Load cell } \\
\text { reading } \\
\text { (lbf) }\end{array}$ \\
\hline \hline 1 & 30 & 0.156 & 16 & 241 & 54 \\
1.125 & 30 & 0.218 & 20 & 245 & 59 \\
1.25 & 30 & 0.218 & 17 & 245 & 58 \\
1.375 & 30 & 0.281 & 20 & 241 & 48 \\
\hline 1 & 40 & 0.156 & 16 & 241 & 47 \\
1.125 & 40 & 0.203 & 18 & 245 & 54 \\
1.25 & 40 & 0.203 & 16 & 245 & 49 \\
1.375 & 40 & 0.25 & 18 & 245 & 55 \\
\hline 1 & 60 & 0.312 & 31 & 245 & 43 \\
\hline
\end{tabular}

The last row is the original spring supplied by Schilling, all others are by PI

Urethane

Graph 1: Elastomer Spring Test (Evaluation 2)

For FRS Fuel Retrieval Tool

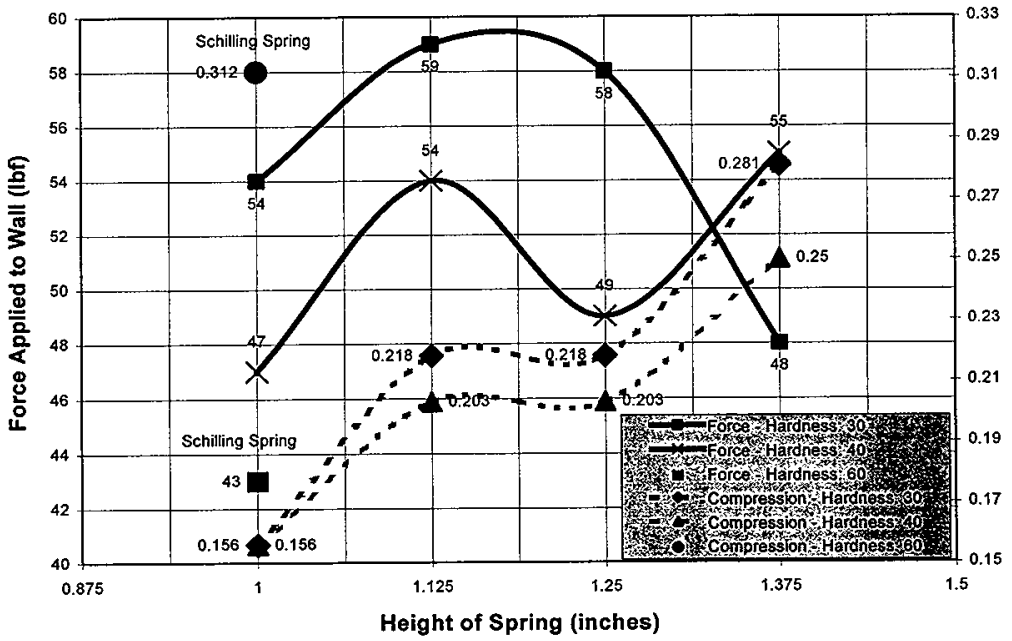

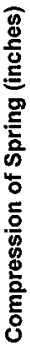

Appendix D- 4 


\section{FRS Test Report For The Evaluation of \\ The Fuel Handling Tool's \\ Large Elastomer Spring}

HNF-3526 Rev. 1

January 28, 1999

\subsection{Problems}

There were no problems encountered in this test. It was observed that there were minor residual indentations resulting from the spring being compressed.

\subsection{Evaluation 3}

\subsection{Results}

\subsubsection{Setup}

The test used a pipe with a machined inside diameter of 1.779 inches and a surface finish of 63shape turn. This is the worst likely condition the spring could encounter. A compression device was fabricated to compress the spring while in the tube by tightening a nut. With a spring in the pipe, the pipe would then be secured to the inside a metal box capable of holding water. The spring would then be hooked to a dynamometer via a wire rope and the dynamometer would then be attached to ratchet pulling device. The total springs tested were: 1.0 inches long with a shore hardness of 30 , 1.125 inches long with a shore hardness of $30,1.25$ inches long with a shore hardness of 30 , and 1.0 inches long with a shore hardness of 60 (Schilling supplied). The test setup can be seen in pictures 14-18 in Appendix E.

\subsubsection{Test}

The following are typical steps used to test a spring. A spring was placed on the compression device (as depicted in the test spec sketch) and positioned such that the spring is just starting to compress. The device was then placed inside the pipe and positioned to have the pulling end compression fitting flush with the pipe entrance. From the other side of the pipe, a depth measurement was taken from the pipe entrance to the compression device. This measurement was used as the baseline for determining the amount of compression applied to the spring. The spring was compressed by turning the screw down until the values from evaluation 2 (see Table 1) are obtained. The pipe was then placed inside a box used to hold it down for pulling and to contain water for the water test. A wire rope with a breaking strength above $500 \mathrm{lbs}$. was then attached to the spring compression device. The other end of the rope was then attached to a dynamometer. The ratchet-pulling device was attached to the other end of the dynamometer.

The ratchet would slowly apply a pulling force on the spring/dynamometer. The dynamometer force was constantly read during testing and the maximum force was noted before the spring showed signs of pulling out. Once a spring reached the critical pulling force, it would slowly start to pull out. Loading was applied slowly with brief stops at every 5 lbs.

Testing with water was performed after completing dry testing. Water testing had the same procedure setup except the spring would be immersed in water before compressing it and the pipe was fully immersed in water when pulling the spring. 


\section{FRS Test Report For The Evaluation Of \\ The Fuel Handling Tool's \\ Large Elastomer Spring}

HNF-3526 Rev. 1

January 28, 1999

\subsubsection{Test Data}

Initially, two springs were tested, the1.125-inch long and 1.25-inch long spring. Dry tests showed that the springs pulled out at a pulling force of about $25 \mathrm{lbf}$. These results were not acceptable since a single outer element weighs upward to $35 \mathrm{lbs}$. The Schilling supplied spring was tested too and it failed at around $25 \mathrm{lbf}$.

\subsection{Problems}

An investigation was made to determine why the Schilling supplied spring worked for the Konan testing but failed this test. An examination of the pipes showed there were two major differences. The pipe used in the Konan tests had a different diameter and surface finish. It's internal diameter was 1.691 inches (equal to the smallest internal diameter of an element) and had a rougher surface finish of 125 profiled.

The tests were again repeated with a piece of the pipe used from the mockup Konan testing. Difficulties were experienced inserting the PSI springs into the pipe because they were too large. The four springs (with a shore hardness of 30 ) had the outside diameter uniformly ground to ensure they would fit inside the pipe. The springs were ground by securing a spring on a spindle and placing it at an angle against a rotating sanding belt with 60 grit paper. This produced a rougher surface finish on the spring and a better gripping action. The original outside diameter for the PSI purchased springs was 1.72 inches and was ground to 1.60 inches.

The ground springs were retested using the test in evaluation 2 in order to determine the change in the amount of compression. Because the springs' diameters were reduced, the load cell readings were also reduced but the compression increased. The 1-inch spring was chosen due to its highest load cell reading. Results are tabulated in Table 2.

\section{Table 2 FRS Fuel Retrieval Tool Spring Test Results (Evaluation 2) Retesting using a spring OD of $\mathbf{1 . 6 0}$ inches}

Old values shown in ()

\begin{tabular}{|c|c|c|c|c|c|c|c|c|c|}
\hline $\begin{array}{l}\text { Spring } \\
\text { Length } \\
\text { (inches) }\end{array}$ & $\begin{array}{l}\text { Hardness } \\
\text { (shore A) }\end{array}$ & \multicolumn{2}{|c|}{$\begin{array}{c}\text { Compression } \\
\text { (inches) }\end{array}$} & \multicolumn{2}{|c|}{$\begin{array}{c}\text { Percent } \\
\text { compression } \\
(\%)\end{array}$} & \multicolumn{2}{|c|}{$\begin{array}{c}\text { Force applied } \\
\text { (lbf) }\end{array}$} & \multicolumn{2}{|c|}{$\begin{array}{l}\text { Load cell } \\
\text { reading } \\
(\mathrm{lbf})\end{array}$} \\
\hline $\begin{array}{c}1 \\
1.125\end{array}$ & $\begin{array}{l}30 \\
30\end{array}$ & $\begin{array}{l}3125 \\
.25\end{array}$ & $\begin{array}{l}(0.156) \\
(0.218)\end{array}$ & $\begin{array}{l}31 \\
22\end{array}$ & $\begin{array}{l}(16) \\
(20)\end{array}$ & $\begin{array}{l}244 \\
240\end{array}$ & $\begin{array}{l}(241) \\
(245)\end{array}$ & $\begin{array}{l}\overline{49} \\
46\end{array}$ & $\begin{array}{l}(54) \\
(59)\end{array}$ \\
\hline $\begin{array}{c}1.25 \\
1.375\end{array}$ & $\begin{array}{l}30 \\
30\end{array}$ & $\begin{array}{c}- \\
375\end{array}$ & $\overline{2}^{-}$ & 27 & (20) & - & (241) & - & - \\
\hline
\end{tabular}


The test in evaluation 3 was then repeated using the 1-inch spring. Results showed that the spring would not pull out easily while inserted in the small diameter pipe but failed when inserted in the large diameter/ smooth pipe. This data was tabulated in Table 3 . The Schilling supplied spring was retested too and the results were the same. Testing was concluded at this point. It was apparent that the force applied to a spring, would not be sufficient enough to keep it from coming pulling out of an element under all the circumstances the spring would encounter.

\begin{tabular}{|l|c|c|}
\hline \multicolumn{3}{|c|}{$\begin{array}{c}\text { Table 3 FRS Fuel Retrieval Tool Spring Test Results } \\
\text { (Evaluation 3) Spring Pull Test }\end{array}$} \\
\hline Test Pipe & $\begin{array}{c}\text { Dry Test } \\
\text { Load Cell Final Pull Reading } \\
\text { (lbs) }\end{array}$ & $\begin{array}{c}\text { Woad Cell Fet Test } \\
\text { (lbal Pull Reading } \\
\text { (bs) }\end{array}$ \\
\hline $\begin{array}{l}\text { Smooth Pipe } \\
\text { ID: } 1.779 \text { inches }\end{array}$ & 30 & $15-20$ \\
\hline $\begin{array}{l}\text { Rough Pipe } \\
\text { ID: } 1.691 \text { inches }\end{array}$ & $100+$ stopped after 120 & $52-60$ \\
\hline
\end{tabular}

\subsection{Conclusion}

Based on the results of these evaluations, it was observed that an elastomer spring would not work because it can not exert enough sidewall force within the large internal diameter of a large fuel element. The amount of sidewall force is a direct relation to the compressibility of the spring's elastomeric properties. A low sidewall force will result in the spring slipping when pulled on and thus the element can not be lifted. 


\section{Appendix E}

Pictures of Tests 


\section{Test Pictures For The FRS Spring Test Report. Test Report: HNF-3526 REVI}

\section{EVALUATION 1}

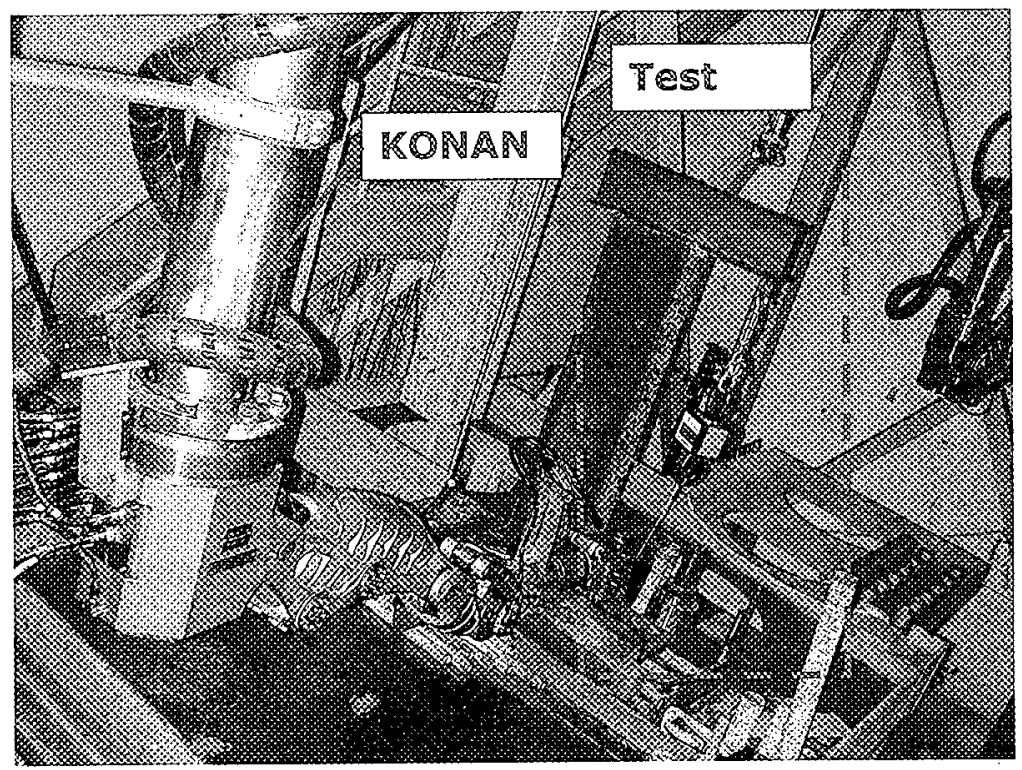

Picture 1 - Konan Arm And Test Set up 
Test Pictures For The FRS Spring Test Report. Test Report: HNF-3526 REVI

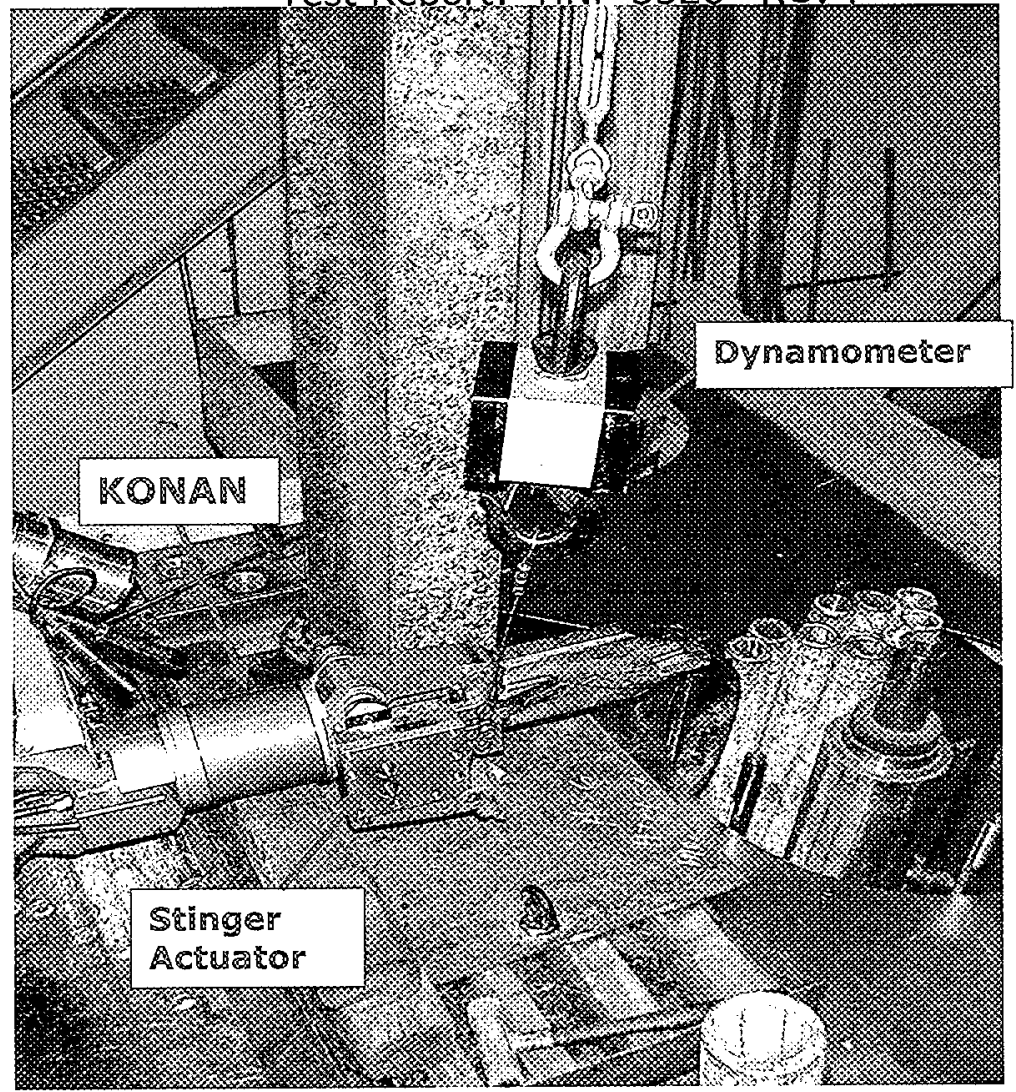

\section{Picture 2 -Test Setup}




\section{Test Pictures For The FRS Spring Test Report. Test Report: HNF-3526 REV I}

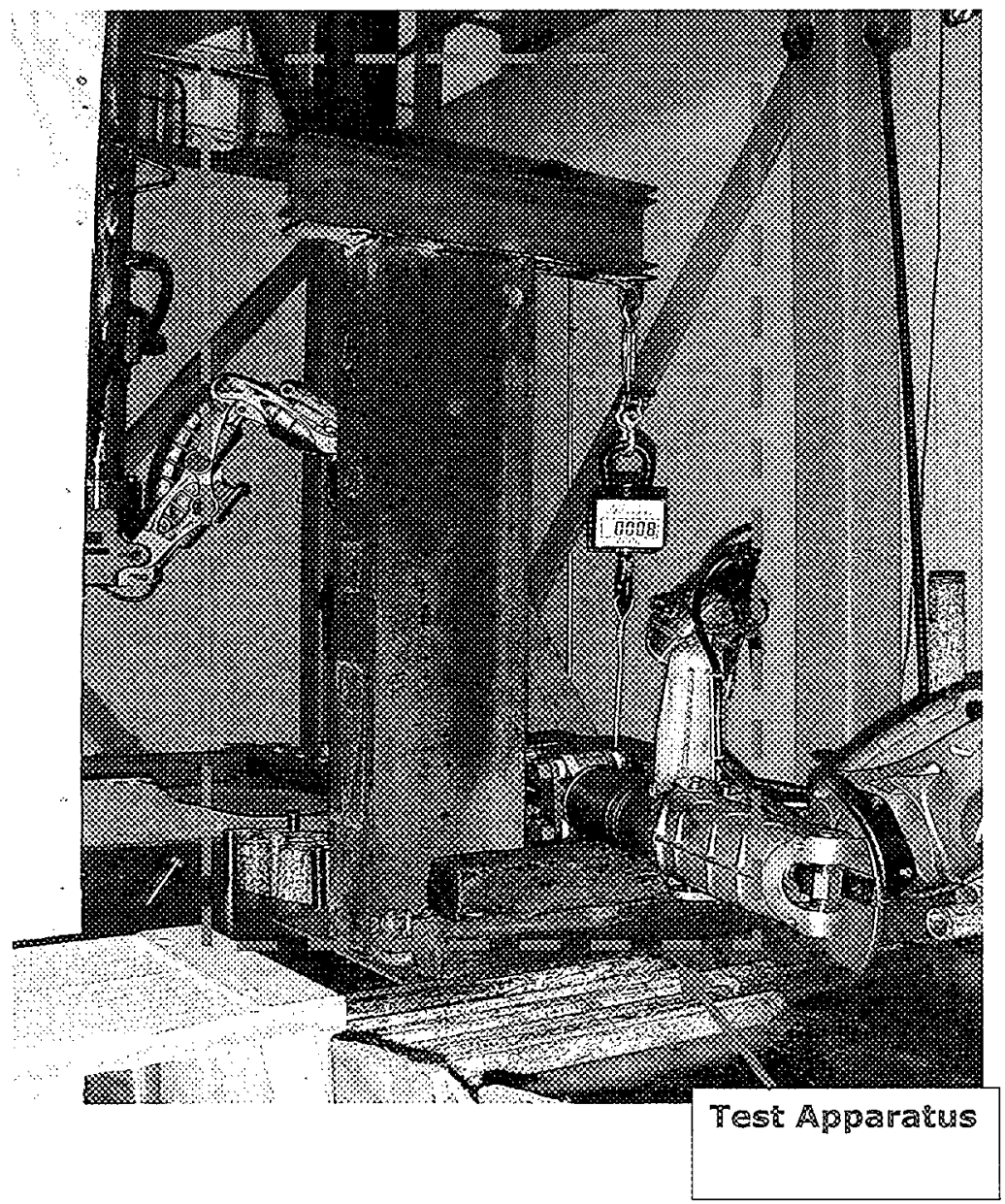

Picture 3 - Dynamometer Readout 


\section{Test Pictures For The FRS Spring Test Report. Test Report: HNF-3526 REV I}

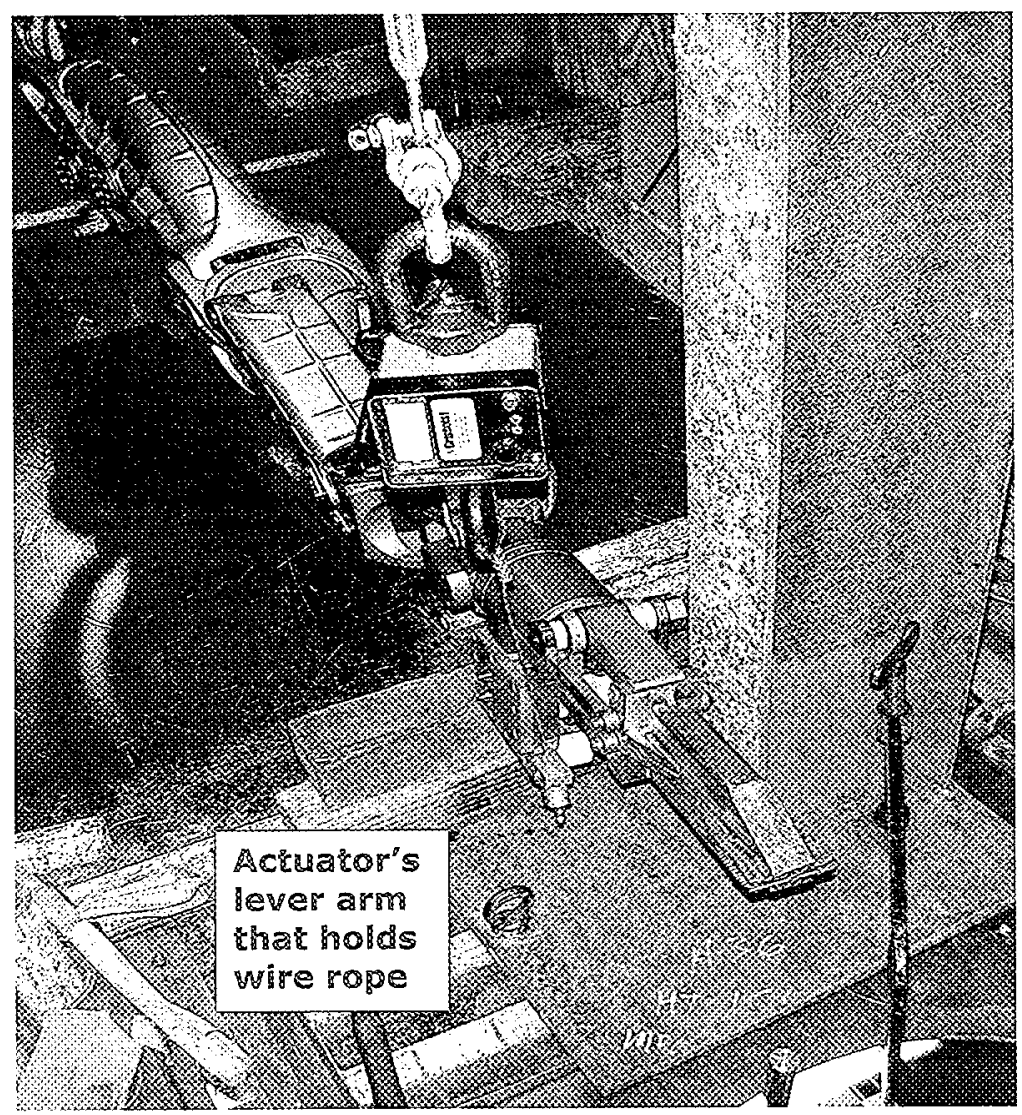

Picture 4- Back View of Test Set Up 


\section{Test Pictures For The FRS Spring Test Report. Test Report: HNF-3526 REV I \\ EVALUATION 2}

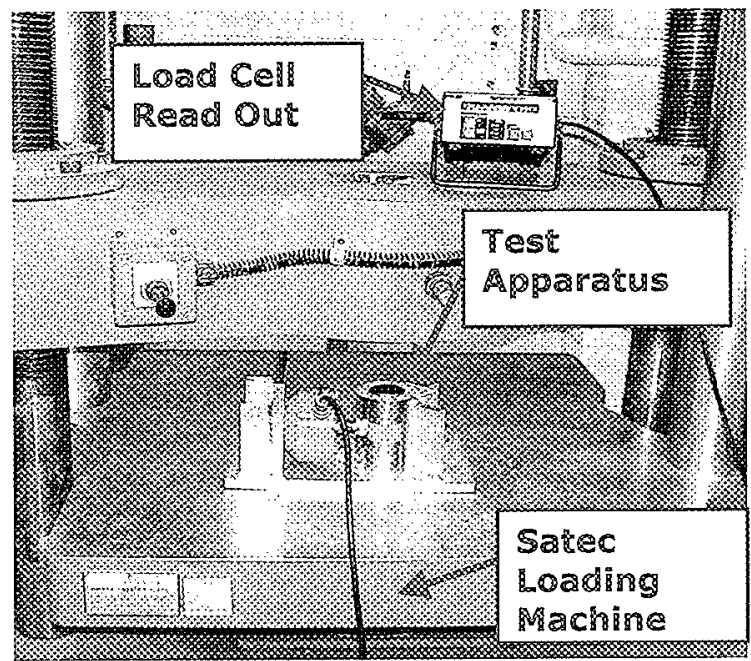

\section{Picture 5 -Test Apparatus}

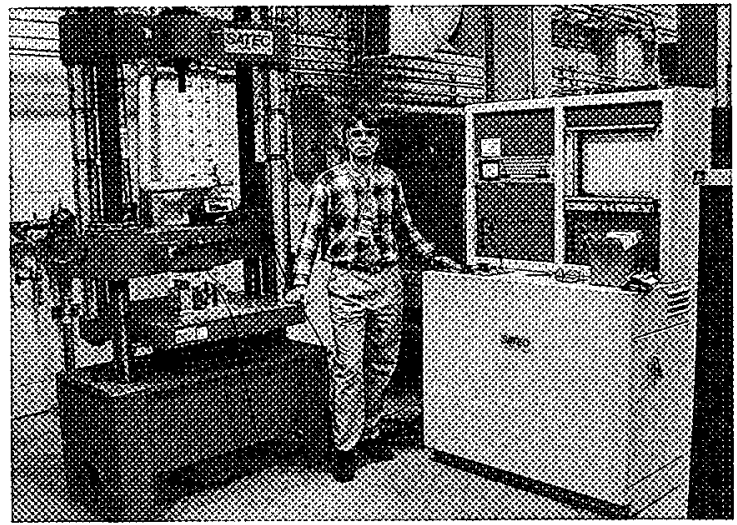

Picture 6 - Full Test Setup 


\section{Test Pictures For The FRS Spring Test Report. Test Report: HNF-3526 REV I}

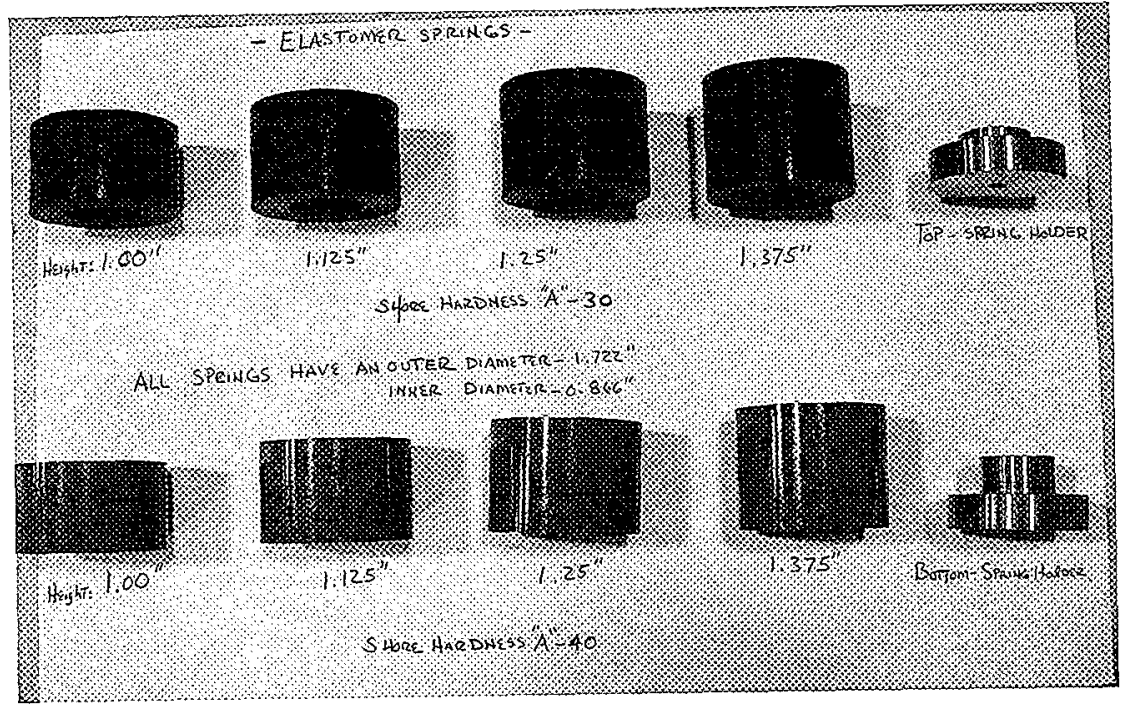

\section{Picture 7 - Tested Springs and Holder}

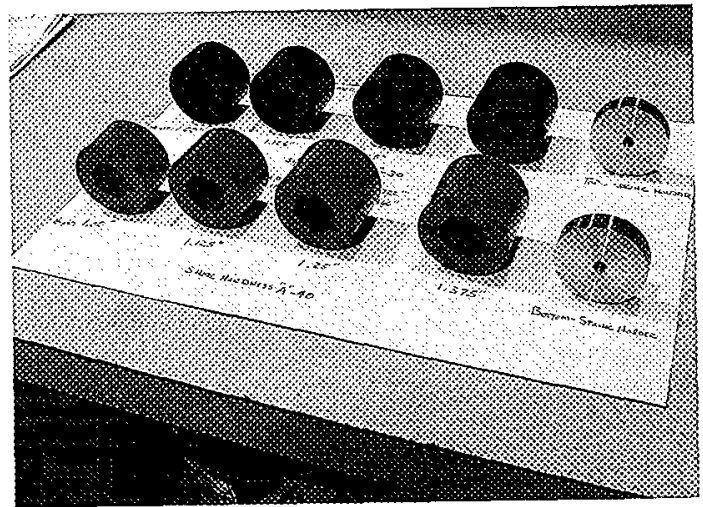

Picture 8 - Side View of Springs 


\section{Test Pictures For The FRS Spring Test Report. Test Report: HNF-3526 REV I}

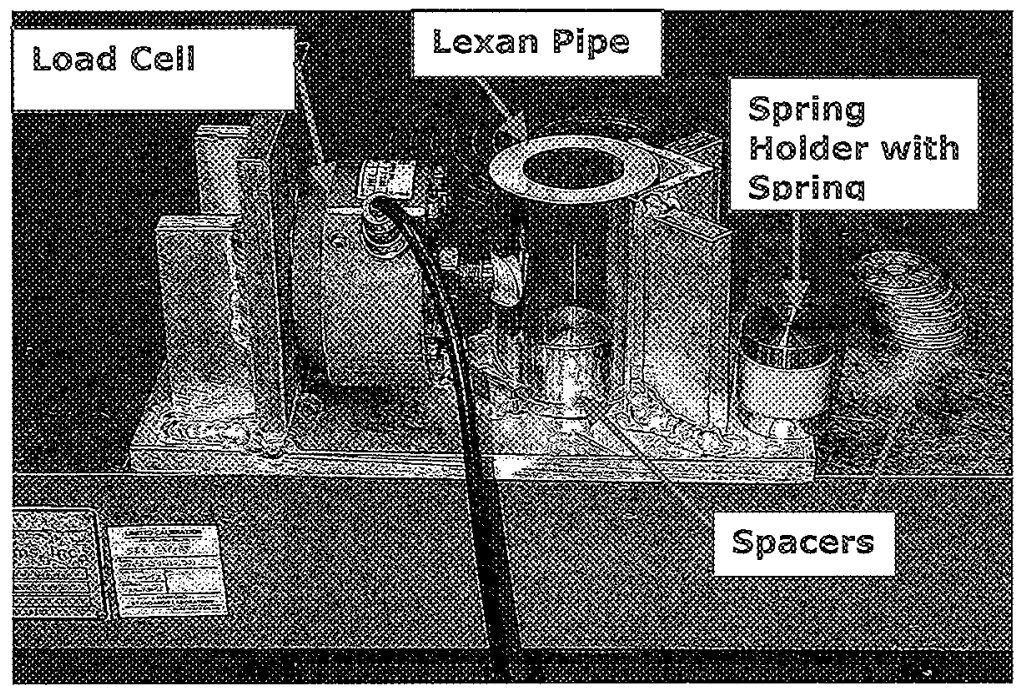

\section{Picture 9 - Test Apparatus}




\section{Test Pictures For The FRS Spring Test Report. Test Report: HNF-3526 REV I}

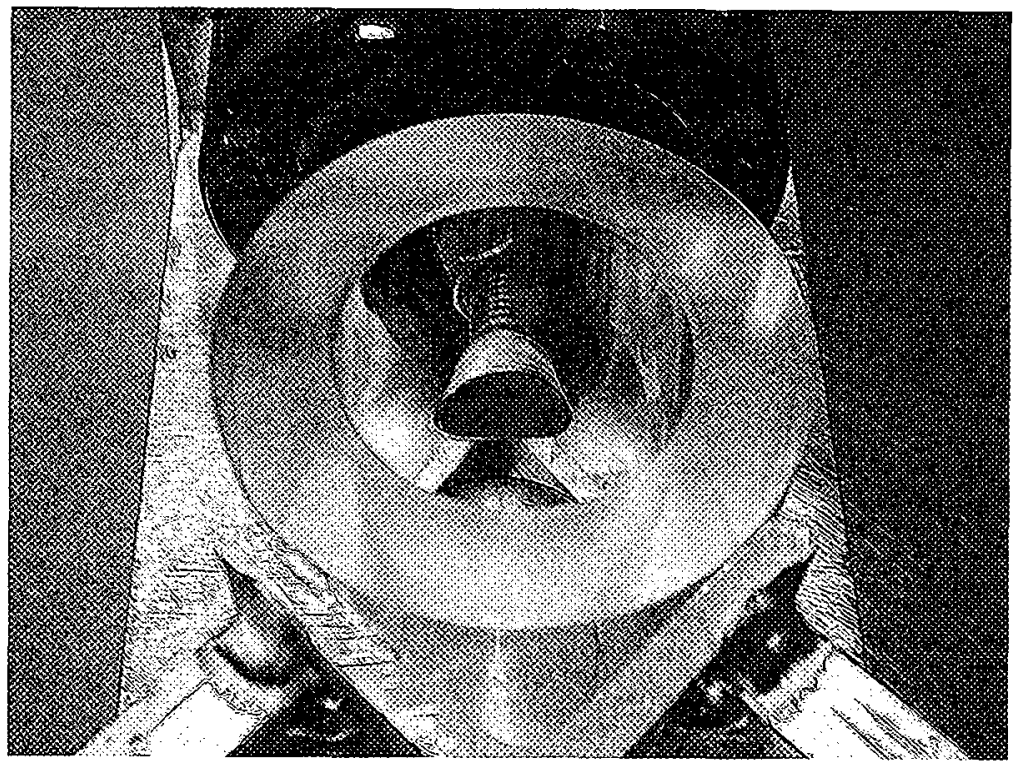

\section{Picture 10 - View of Load Cell Extension Rod}




\section{Test Pictures For The FRS Spring Test Report. Test Report: HNF-3526 REV I}

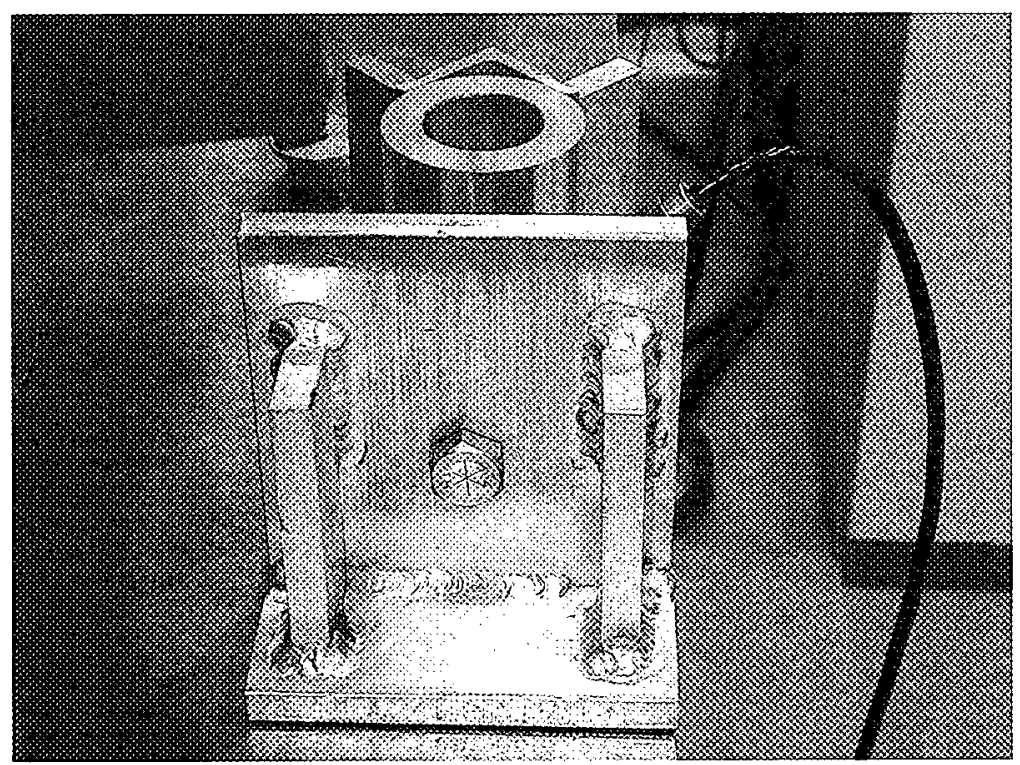

Picture 11- Side View of Test Apparatus 


\section{Test Pictures For The FRS Spring Test Report. Test Report: HNF-3526 REVI}

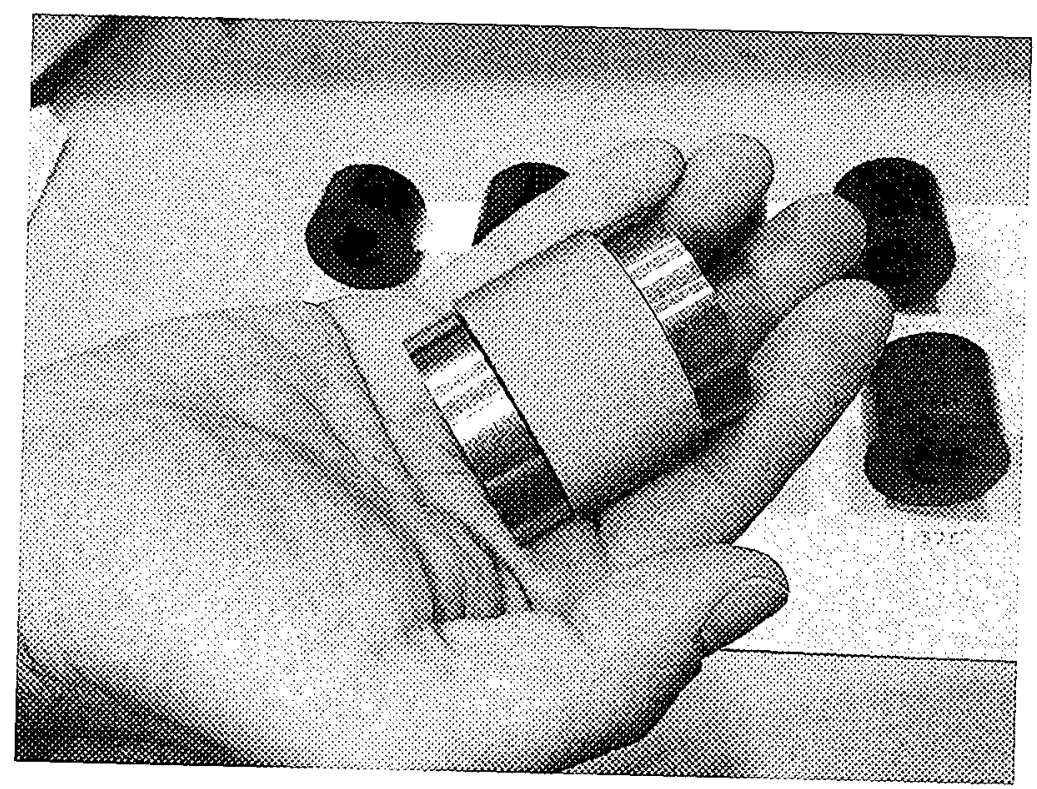

Picture 12 - Spring Holder and Spring 


\section{Test Pictures For The FRS Spring Test Report. Test Report: HNF-3526 REVI}

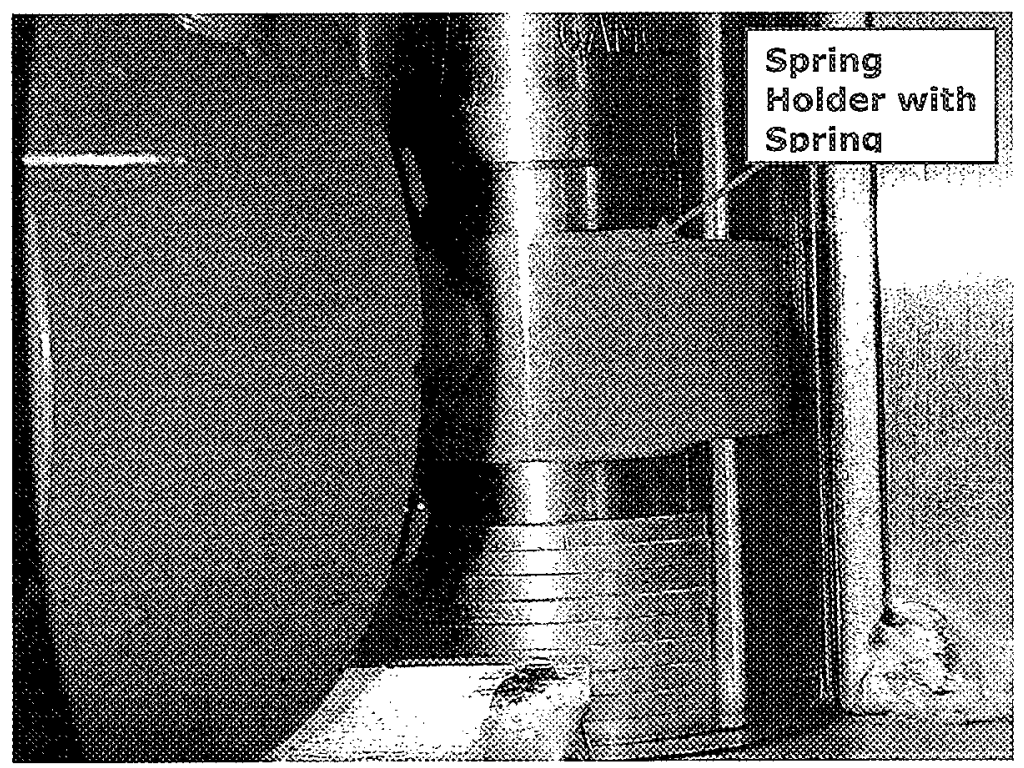

Picture 13 - Spring Under Compression 


\section{Test Pictures For The FRS Spring Test Report. Test Report: HNF-3526 REVI}

\section{EVALUATION 3 - Spring Pull Test}

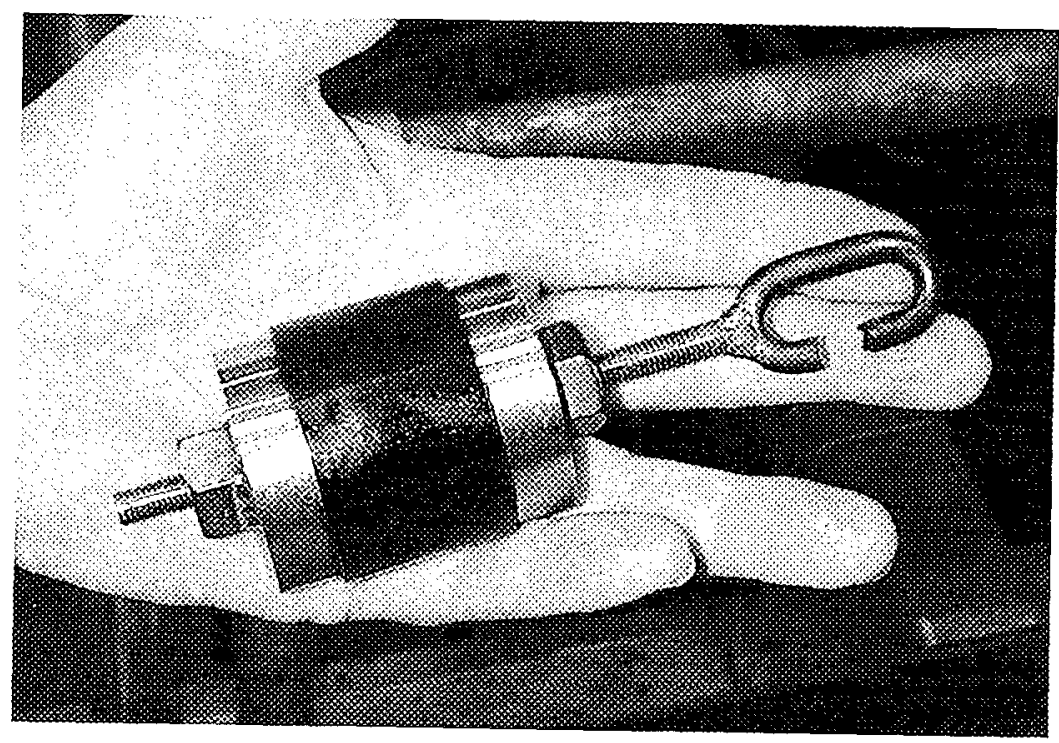

\section{Picture 14 - Spring Loaded in Compression Device}




\section{Test Pictures For The FRS Spring Test Report. Test Report: HNF-3526 REVI}

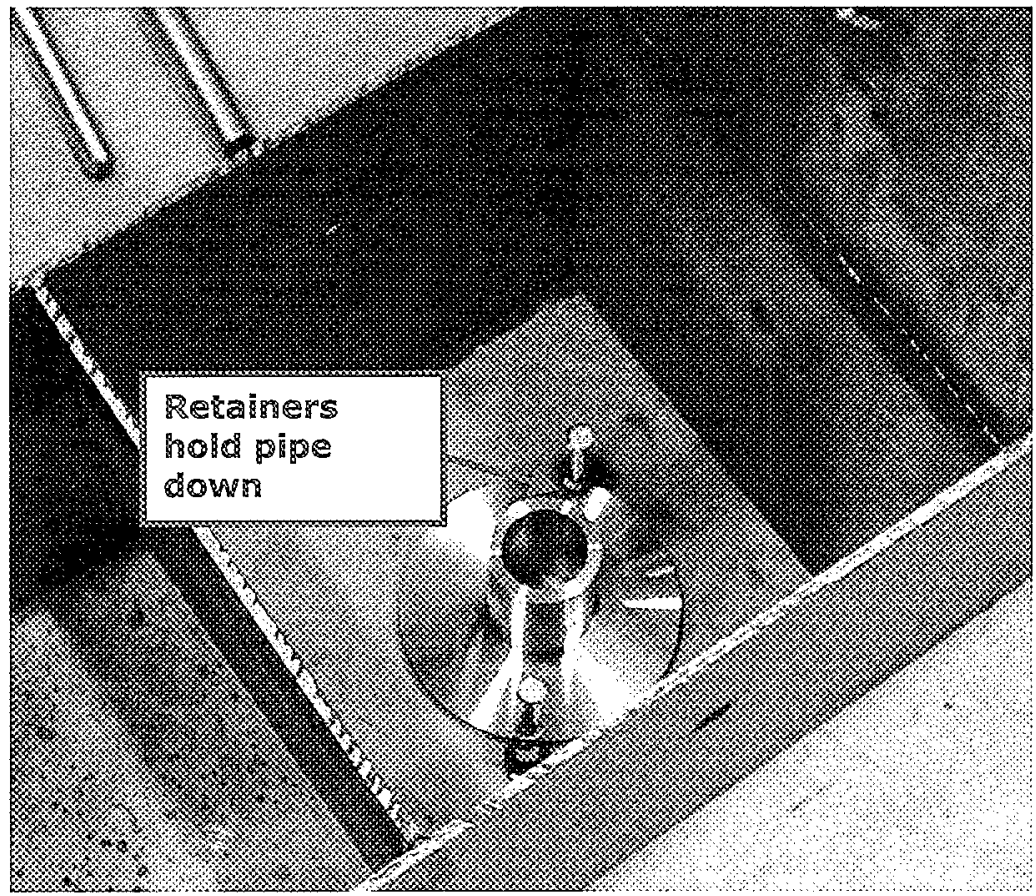

Picture 15 - Smooth Pipe Attached to Box 


\section{Test Pictures For The FRS Spring Test Report. Test Report: HNF-3526 REV I}

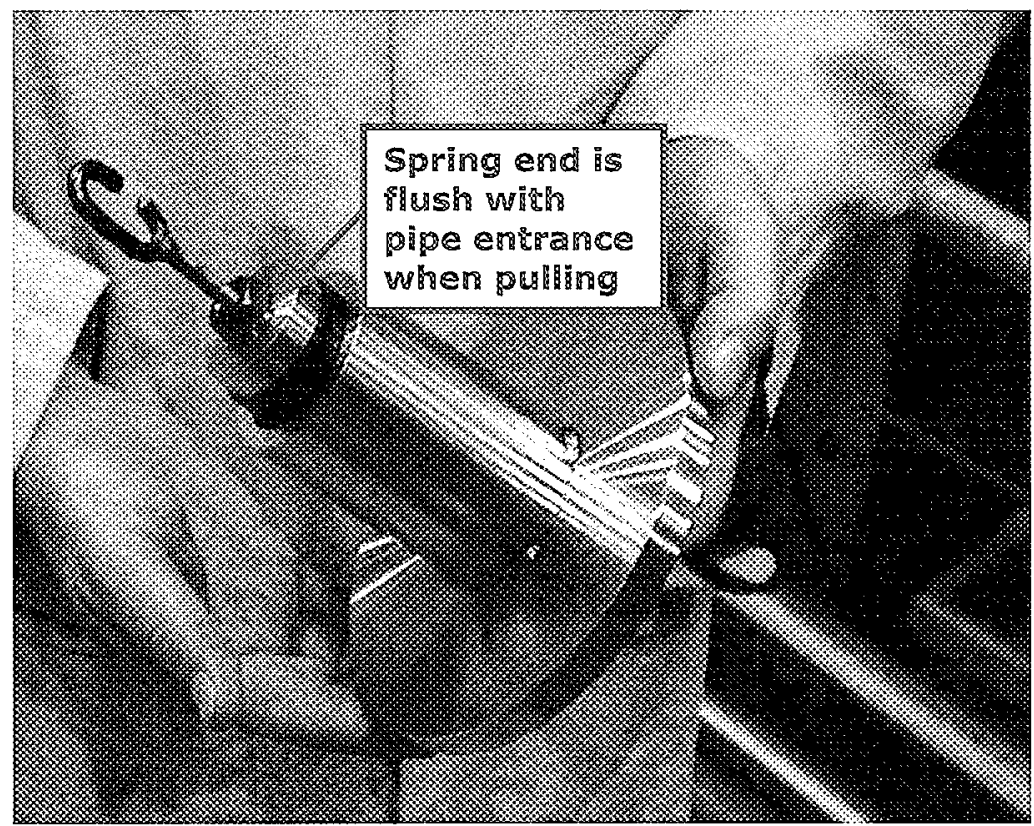

Picture 16 - Spring in Smooth Pipe for Pull Test 


\section{Test Pictures For The FRS Spring Test Report. Test Report: HNF-3526 REVI}

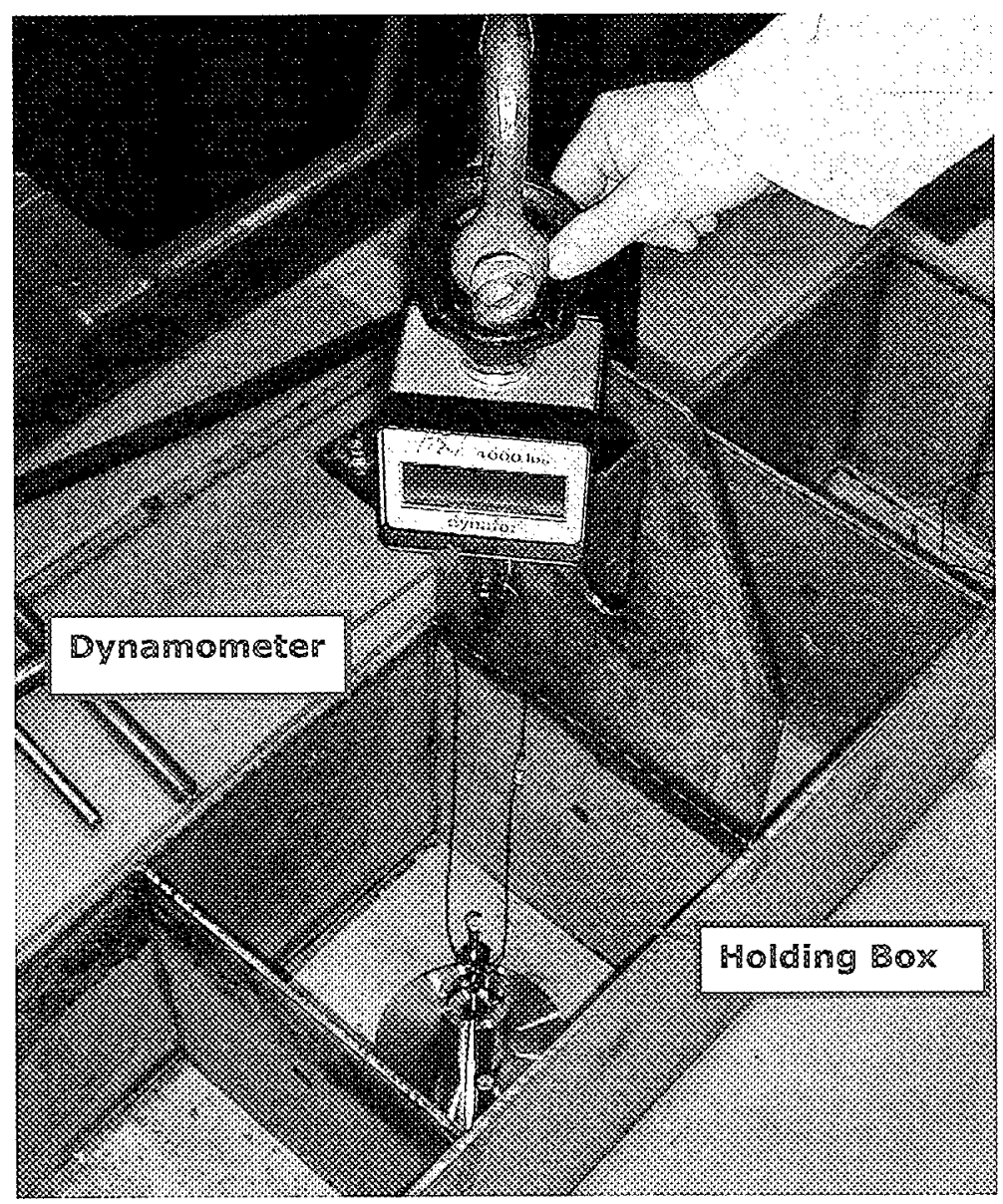

\section{Picture 17 - Dynamometer Attachment Setup}




\section{Test Pictures For The FRS Spring Test Report. Test Report: HNF-3526 REV I}

\section{Picture 18 - Setup of Pull Test}

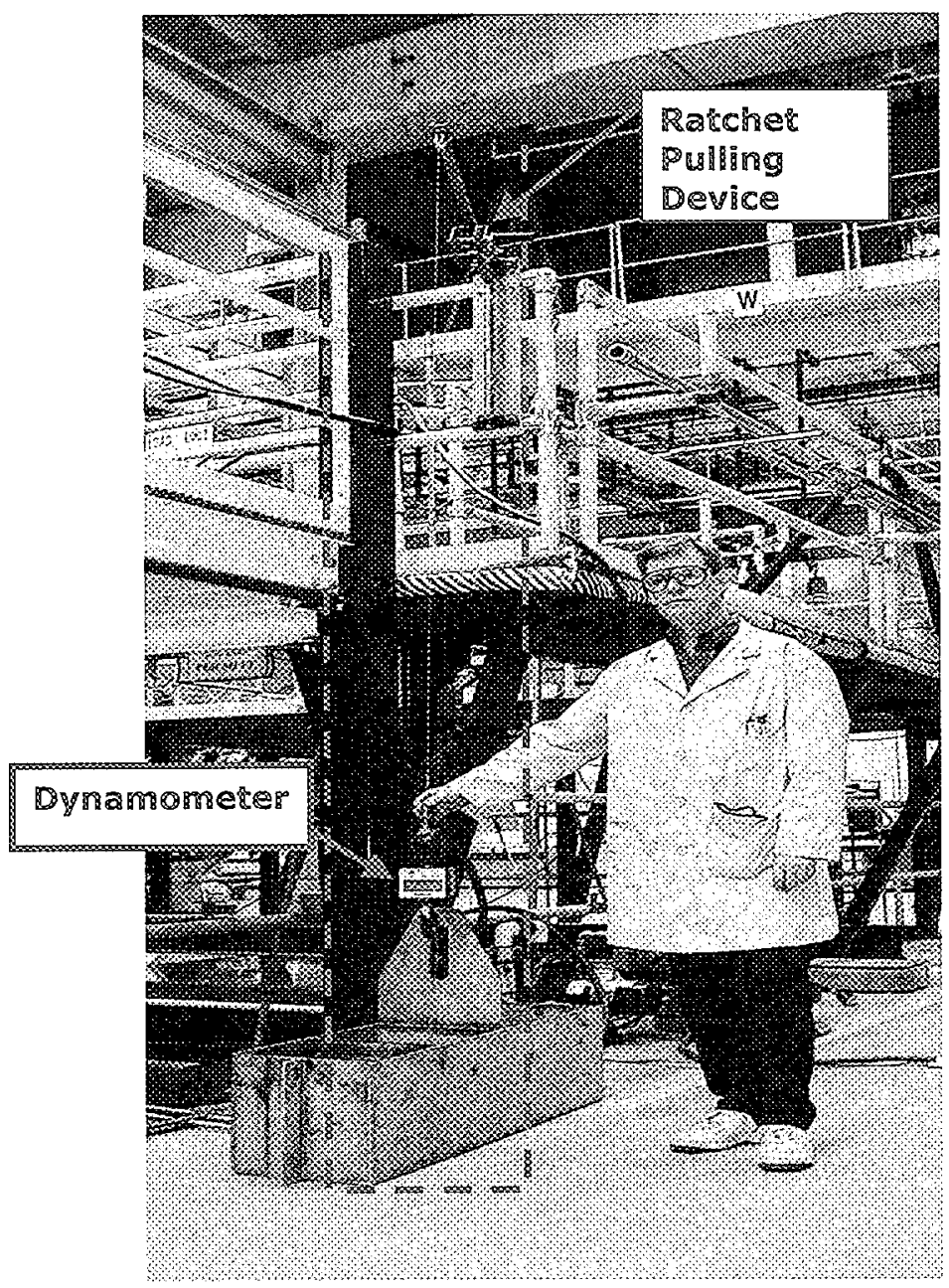

